\title{
Color and Scent: How Single Genes Influence Pollinator Attraction
}

\author{
H. Sheehan, K. Hermann, And C. Kuhlemeier \\ Institute of Plant Sciences, Altenbergrain 21, CH-3013 Bern, Switzerland \\ Correspondence: cris.kuhlemeier@ips.unibe.ch
}

\begin{abstract}
A major function of angiosperm flowers is the recruitment of animal pollinators that serve to transfer pollen among conspecific plants. Distinct sets of floral characteristics, called pollination syndromes, are correlated with visitation by specific groups of pollinators. Switches among pollination syndromes have occurred in many plant families. Such switches must have involved coordinated changes in multiple traits and multiple genes. Two well-studied floral traits affecting pollinator attraction are petal color and scent production. We review current knowledge about the biosynthetic pathways for floral color and scent production and their interaction at the genetic and biochemical levels. A key question in the field concerns the genes that underlie natural variation in color and scent and how such genes affect pollinator preference, reproductive isolation, and ultimately speciation.
\end{abstract}

Pollination syndromes are sets of floral traits that are adapted to different guilds of animal pollinators (Faegri 1979; Fenster et al. 2004). The floral traits that constitute a particular pollination syndrome can be separated into three categories: traits that attract the pollinator, such as floral color and scent; traits that reward the pollinator, such as nectar volume; and efficiency traits, such as the positioning of reproductive organs that affect pollen removal and deposition (Bradshaw et al. 1995). Although it is debated whether pollination syndromes can accurately predict the type of pollinating visitor to a flower, the pollination syndrome concept is a useful way to try to understand floral diversification and to frame questions about evolutionary transitions (Waser et al. 1996; Kingston and Mc Quillan 2000; Fenster et al. 2004; Ollerton et al. 2009; Danieli-Silva et al. 2012). Pollination syndromes can be considered as a spectrum, with generalist species that produce flowers that appeal to many pollinators at one end and flowers that require pollination by specific pollinators at the other end (Fenster et al. 2004).

The force behind the convergent evolution of pollination syndromes across plant families is thought to be selection pressure exerted by the particular guilds of pollinators (van der Pijl 1960; Faegri 1979; Fenster et al. 2004). Animals have an innate preference for certain floral attributes and/or learn to associate the flower with providing a food source, such as nectar or pollen (Riffell 2013). In cases in which a variant arises that is more attractive to a particular pollinator, this will lead to a higher number of pollinator visits and may result in an increase in the fitness of the plant. This increase in fitness can cause the trait to spread as the variant allele increases in frequency in the population.

Floral constancy shown by the pollinator causing assortative mating may then lead to prezygotic isolation and possibly even speciation. This process has traditionally been thought of as coevolutionary, with plants also exerting selection on pollinators (Feinsinger 1983). However, more recent work in traits of attraction, color and scent has suggested that the plants have adapted their traits to sensory capabilities already present in the pollinators (Schiestl and Dötterl 2012), although there may be some fine-tuning of pollinator sensory preferences (Chittka and Menzel 1992; Raine and Chittka 2007).

Switches among syndromes are widespread. For instance, in the Solanaceae, hummingbird pollination is thought to have arisen at least 10 times (Knapp 2010). This raises the question of the genetic basis of the evolution of pollination syndromes. If each of the individual traits is encoded by multiple genes that must coordinately evolve, how is it possible that switches among syndromes happen frequently? To answer this question, it is necessary to identify the underlying plant genes that are under selection by animal pollinators. In their seminal study, Bradshaw et al. $(1995,1998)$ investigated the genetic bases for multiple divergent pollination syndrome traits in the monkey flower Mimulus. In its natural habitat, Mimulus lewisii is pollinated by bumblebees, whereas M. cardinalis is pollinated by birds. The two species live in habitats that are altitudinally separated except for a hybrid zone in which they overlap. Although the species are cross-compatible, they are almost completely reproductively isolated by the different pollinators that they attract (Schemske and Bradshaw 1999; Ramsey et al. 2003). To investigate the genetics defining the differences in pollination syndromes between these two species, a quantitative trait locus (QTL) analysis was performed. It was found that all of the pollination syndrome traits investigated (which included traits of pollinator attraction, reward, and efficiency) could be explained by one to six QTLs each (Bradshaw et al. 1995). This implies that there may only be a limited number of genes that determine 
differences in individual pollination traits and that genes of large effect may have a central role in the pollinatordetermined prezygotic isolation of plant species.

Quantitative trait loci analysis provides rough map positions, and each of the identified loci may still consist of multiple linked genes. Thus, the next logical step is to identify the genes underlying the QTL. The search for "pollination syndrome genes" in plants has been in full progress during the last 10 years. Once isolated, it is possible to determine the number and nature of the genetic changes required to change an individual floral trait. Do genetic changes preferably occur in structural or in regulatory genes and is there evidence for selection? Interspecific crosses followed by reciprocal introgressions of single loci also provide attractive material for pollinator choice studies, both under controlled laboratory conditions and in the natural habitat. They make it possible to determine the extent to which differences in single traits/ loci condition differences in pollinator visitation and their effect on female and male fitness in the plant. Ultimately, transgenic lines can determine the effect of single genes.

It is important here to make the distinction between gene polymorphisms that have arisen in nature (natural variants) versus those that have arisen in the laboratory (mutants) or by breeding (varieties). Most mutants and varieties will have reduced overall fitness and are unlikely to survive in the wild. Thus, we focus here on natural color variants and the genes that determine these.

So far, the molecular basis of natural variation is known for only two pollination syndrome traits: petal color, specifically anthocyanin-based color, and scent production. We discuss the types of genes that have been found, their role in the attraction of different classes of pollinators, and the similarities among species. We focus specifically on anthocyanin-based petal color and volatile benzenoid-derived scent, both of which are derived from phenylalanine (see Fig. 1). We base our discussion around the genus Petunia, in which the biochemistry and molecular genetics of the two pathways have been worked out in considerable detail.

The genus Petunia comprises 14 species, 11 of which show a typical bee pollination syndrome (Stehmann et al. 2009). Petunia integrifolia, a representative of the bee clade, has a purple corolla with a wide tube that gives bees access to the nectar, and stamens and stigma within the length of the tube (Fig. 2A) (Stuurman et al. 2004). Petunia axillaris possesses a hawkmoth pollination syndrome (Fig. 2B), with white flowers that produce a strong scent at dusk. Hawkmoths reach the abundant dilute nectar by extending their probosces through the long, narrow floral tubes (Stuurman et al. 2004). P. integrifolia conforms to its pollination syndrome, with visits primarily by

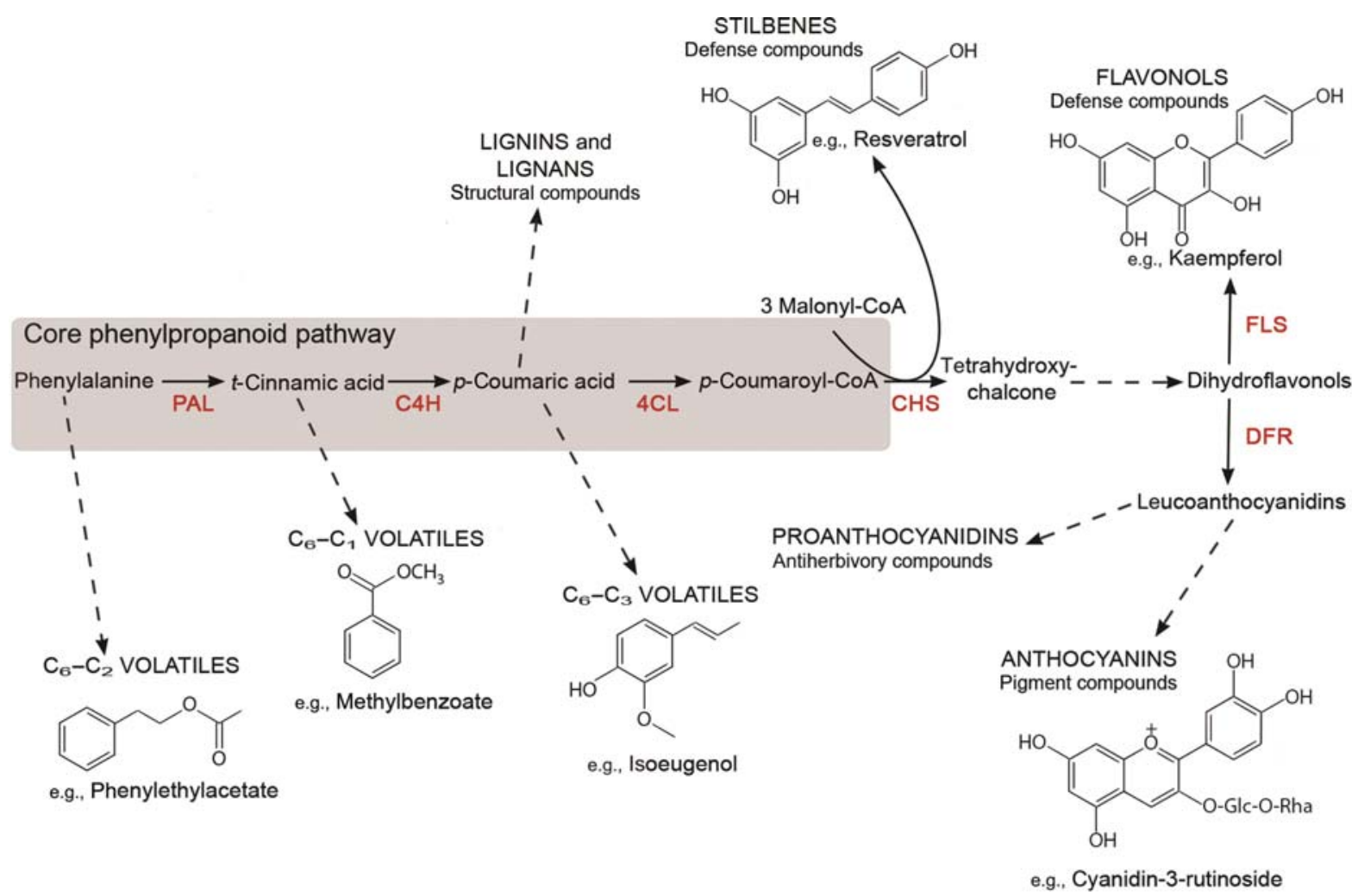

Figure 1. The amino acid phenylalanine is the common precursor of volatile benzenoids, flavonoid pigments, and other secondary metabolites with diverse functions. The positions of major products in the pathway are depicted. Enzymes are shown in red. Black arrows indicate a single enzymatic step; dashed arrows indicate more than one enzymatic step. (4CL) 4-Coumarate CoA-ligase, (C4H) cinnamate 4-hydroxylase, (CHS) chalcone synthase, (DFR) dihydroflavonol reductase, (FLS) flavonol synthase, (PAL) phenylalanine ammonia lyase. 


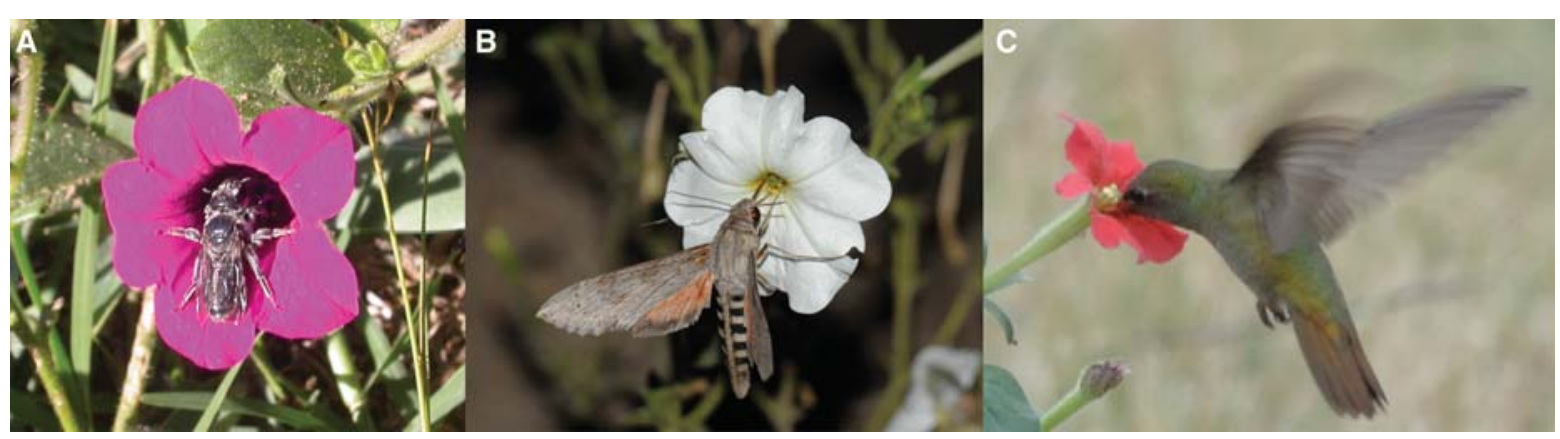

Figure 2. Closely related Petunia species attract different animal pollinators: Petunia integrifolia with the solitary bee species Callonychium petuniae (A), Petunia axillaris ssp. axillaris with the hawkmoth Hyles lineata, Uruguay 2008 (B), Petunia exserta lab-line with the hummingbird Hylocharis chrysura, Uruguay 2009 (C). Photographs: Alexandre Dell'Olivo.

bee species (Gübitz et al. 2009), whereas P. axillaris is pollinated by both nocturnal hawkmoths and diurnal bees (Hoballah et al. 2007). Petunia exserta has bright red petals that are reflexed, with the reproductive organs exserted from the floral tube (Fig. 2C) (Gübitz et al. 2009). These traits are typical for the hummingbird pollination syndrome, but detailed field observations of this rare species are scarce (Lorenz-Lemke et al. 2006).

\section{FLORAL COLOR}

\section{Floral Color Can Influence Pollinator Behavior in Different Ways}

Particular floral colors characterize different pollination syndromes and are associated with particular classes of pollinators. This must be conditioned in part by the perceptive abilities of the pollinators. All insects can see into the ultraviolet (UV) but have limited ability to see into the red end of the light wavelength spectrum (Menzel and Backhaus 1991). Pollinating birds have four photoreceptors with peak sensitivities in the UV, blue, green, and red light ranges (Herrera et al. 2008). The association of floral colors with particular pollinators is also likely to be affected by innate color preferences held by the pollinators. Innate preferences have been shown in many species to initially attract pollinators or aid recognition of flowers (Giurfa et al. 1995; Kelber 1997; Weiss 1997; Gumbert 2000; Goyret et al. 2008). For instance, bee pollination syndromes are associated with blue and yellow flowers (Faegri 1979). Bees have photoreceptors for blue, green, and UV light (for review, see Chittka and Raine 2006) and both bumblebees and honeybees show innate preferences for blue wavelengths (Giurfa et al. 1995; Gumbert 2000). However, innate preferences do not always match the pollination syndrome. Hawkmoths display an innate preference for blue despite the prevalence of white, UV-absorbing flowers being pollinated by hawkmoths (Goyret et al. 2008). Other pollinators do not seem to have innate preferences at all. For instance, the hummingbird pollination syndrome is associated with red flowers; however, hummingbirds do not have an innate preference for red (Miller and Miller 1971). Rather, the color association may have evolved in avoidance of competition with bees, because detection of red flowers by bees may not be as efficient as detection of other colors (Spaethe et al. 2001; Lunau et al. 2011).

Associative learning is also used by pollinators to determine which particular colored flowers will provide a reward (Bené 1941; Miller and Miller 1971; Weiss 1997; Goyret et al. 2008). In some cases, learned colors may become stronger than innate preferences (Kelber 1997; Goyret et al. 2008). In other cases, it seems that innate color preferences are valued at a similar level (Weiss 1997) or may come into play again when learned colors are not helpful (Gumbert 2000). For instance, in honeybees, floral constancy has been shown for short bouts of foraging that could be attributed to associative learning and short-term memory (Raine and Chittka 2007), although innate preferences are still relevant because honeybees are thought to learn innately preferred colors more rapidly than noninnately preferred colors (Giurfa et al. 1995). Color patterns can also influence the attractiveness of the flower and increase the efficiency of pollination. For example, nectar guides are patterns of contrasting colors, often comprising "bulls-eye" spots at the mouth of the floral tube. Nectar guides increase pollinator efficiency by helping insects to orient on the flower and guide them to the food source more quickly than they would without (Waser and Price 1981, 1983; Dinkel and Lunau 2001).

The question of whether an alteration in floral color alone can affect pollinator attraction was addressed in further work on Mimulus (Schemske and Bradford 1999; Bradshaw and Schemske 2003). The bumblebeepollinated $M$. lewisii possesses pink flowers, whereas hummingbird-pollinated $M$. cardinalis has red flowers. The difference in color can be attributed to one locus, yellow upper (yup), from which the dominant allele from $M$. lewisii prevents carotenoid accumulation, whereas the homozygous recessive yup allele from $M$. cardinalis enables carotenoid accumulation (Bradshaw and Schemske 2003).

Reciprocal introgressions of the yup locus into the parental lines resulted in a yellow-orange $M$. lewisii line and a dark-pink $M$. cardinalis line. Small differences in six other traits important for pollinator visitation were present but were probably not functionally significant (Bradshaw and Schemske 2003). The differences in color 
altered the preferences of the pollinators, decreasing the attraction of the species to its original pollinator and increasing the attractiveness to its noncognate pollinator. This shows that color likely has an important role in maintaining the reproductive isolation of these two Mimulus species. It also indicates that a change at a single locus can alter the pollinator class attracted to a plant. Although at this time the underlying gene (or genes) has not been identified, it seems likely that the yup locus has a role in the regulation or biosynthesis of carotenoid compounds.

Can a change in pollinator preference between two species be pinpointed to a difference in one gene? To study the role of flower color in pollinator attraction, we have used Petunia as a fitting model system. In Petunia, the contrasting color differences in the pollination syndromes are characterized by anthocyanin-based petal colors. The anthocyanin pathway is one of the best-characterized metabolic pathways in plants and much of the biochemical and molecular-genetic studies were performed in Petunia (Holton and Cornish 1995; Koes et al. 2005; Tornielli et al. 2009).

\section{The Anthocyanin Pathway Is a Useful Model in which to Study Differences in Floral Color}

Anthocyanins, a class of flavonoid, are the predominant floral pigment in angiosperms (Winkel-Shirley 2001). Other flavonoids also serve as floral pigments: aurones produce yellow flowers in some species (e.g., see Schwinn et al. 2006), whereas flavonols are important for absorption in the UV light range and can act as copigments in the presence of anthocyanins. Other components, such as the $\mathrm{pH}$ of the vacuoles in which the anthocyanins are stored, can also alter the light-absorption properties of anthocyanin compounds (Grotewold 2006).

The anthocyanin biosynthetic pathway is depicted in Figure 3. Excellent reviews have been written on anthocyanin biosynthesis and its regulation in Petunia and other species (Koes et al. 2005; Grotewold 2006; Quattrocchio et al. 2008; Tornielli et al. 2009). Here, we give a brief overview of the pathway and focus on the main genes that influence color. The early enzymes of the pathway convert phenylalanine to dihydroflavonols (dihydrokaempferol, dihydroquercetin, and dihydromyricetin), the precursors for both anthocyanins and UV-absorbing flavonols. Flavonol synthase (FLS) specifically catalyzes the synthesis of the flavonols, whereas dihydroflavonol reductase (DFR) is the first dedicated enzyme in the anthocyanin branch of the pathway. Anthocyanidin synthase (ANS) establishes the conjugated double-bond structure that makes the molecule appear colored to the human eye. The three main classes of anthocyanidins are orange-red pelargonidins, red-blue cyanidins, and blue-purple delphinidins. Further modification occurs by glucosyltransferases, acyltransferases, and rhamnosyltransferases, and methyltransferases produce "redder" compounds: peonidins from cyanidins, and petunidins and malvidins from delphinidins.
The type of anthocyanins produced can be influenced by the presence/absence as well as substrate specificities of the biosynthetic enzymes. $P$. integrifolia has highly decorated anthocyanins, such as malvidin-3-( $p$-coumaroyl)-rutinoside-5-glucoside (Fig. 3), whereas $P$. exserta produces simple anthocyanins, such as delphinidin-3-rutinoside and cyanidin-3-rutinoside (Fig. 3) (Ando et al. 1999). The low affinity of P. hybrida DFR for dihydrokaempferol and dihydromyricetin results in the production of mainly delphinidin-based anthocyanins (Gerats et al. 1982; Tornielli et al. 2009). This is likely attributable to the specific amino acid sequence in the putative substrate-binding region of DFR (Johnson et al. 2001). Competition for substrates may occur between the different branches of the anthocyanin pathway and/or between the anthocyanin and other branches of the flavonoid pathway. For instance, studies have shown that when a dominant flavonol $(f l)$ locus is present in $P$. hybrida, the anthocyanin biosynthetic genes likely cannot compete against the flavonol biosynthetic gene FLS for the common substrate dihydroquercetin, resulting in a lower production of cyanidin-derived anthocyanins (Gerats et al. 1982).

\section{Regulation of the Anthocyanin Pathway Is by a Conserved Group of Transcription Factors}

Floral pigmentation mutants in Petunia have revealed a number of genes that activate anthocyanin structural genes. $A N 2, A N 1$, and $A N 11$ code for a R2R3-MYB transcription factor (R2R3-MYB), a basic-helix-loop-helix (bHLH) transcription factor, and a WD40-repeat (WDR) protein, respectively. These proteins act in a complex (MYB-bHLH-WDR) to coordinately up-regulate the expression of late anthocyanin biosynthetic genes, from $D F R$ onward (Beld et al. 1989; Quattrocchio et al. 1993). Another, as-yet-unidentified group of regulators must be responsible for expression of the early biosynthetic genes because they are expressed independently (Tornielli et al. 2009). It is proposed that this separate regulation provides a mechanism for the diversification of color while allowing other classes of flavonoids, with other roles in the plant, to be produced in tissues in which anthocyanin pigments are not present (Quattrocchio et al. 2008).

A number of closely related $R 2 R 3-M Y B s$ confer pigmentation in specific tissues. The $R 2 R 3-M Y B A N 2$ is expressed mainly in the petal limb in which it is the major regulator of anthocyanin production, whereas AN4 is primarily responsible for pigmentation in the anthers and floral tube (Quattrocchio et al. 1998, 1999; Kroon 2004). DEEPPURPLE (DPL)/MYBB expression is correlated with flower tube venation, whereas another $R 2 R 3-M Y B$, PURPLEHAZE (PHZ), regulates anthocyanin production in light-exposed tissue in floral buds (Albert et al. 2011). A number of experiments that use ectopic and heterologous expression in mutants show that, in many cases, these $R 2 R 3-M Y B s$ can compensate for the loss of function of native $R 2 R 3-M Y B s$, producing pigmentation in tissues in which they are expressed (Quattrocchio et al. 1998; 


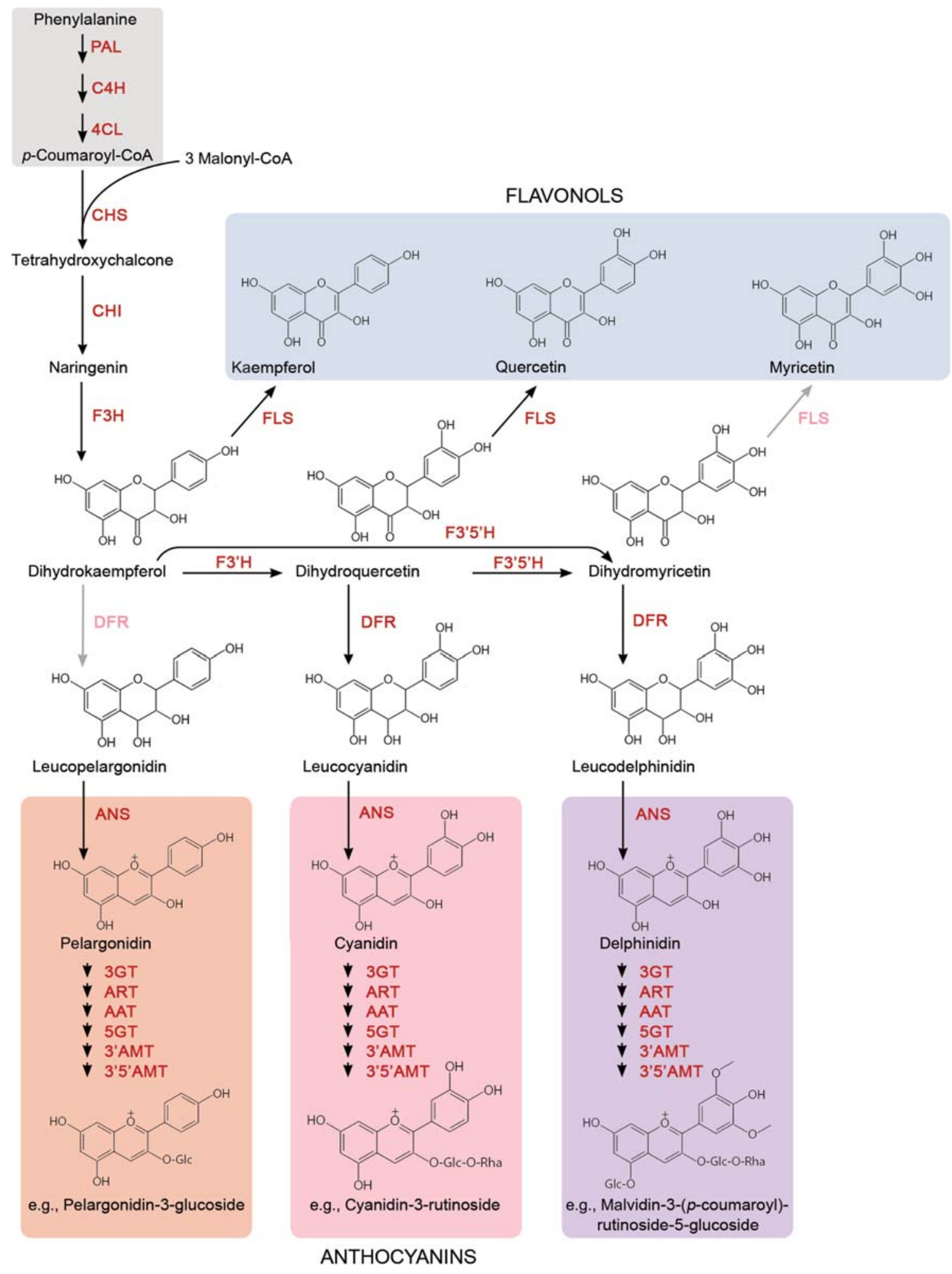

Figure 3. The flavonoid pathway leading to the production of anthocyanins and flavonols in Petunia hybrida. Enzymes are shown in red. Light-red enzyme names and gray arrows leading to the pelargonidins and myricetin indicate enzymatic reactions that do not occur in Petunia hybrida, owing to an inability of the enzyme to use the substrate. ( $3^{\prime}$ AMT and $3^{\prime} 5^{\prime}$ AMT) Anthocyanidin $3^{\prime}$ and $3^{\prime} 5^{\prime} O-$ methyltransferase, (3GT and 5GT) anthocyanidin 3 and 5 glucosyltransferase, (4CL) 4-coumarate CoA-ligase, (AAT) anthocyanidin 3-rutinoside acyltransferase, (ANS) anthocyanidin synthase, (ART) anthocyanidin 3-glucoside rhamnosyltransferase, (C4H) cinnamate 4-hydroxylase, (CHI) chalcone isomerase, (CHS) chalcone synthase, (DFR) dihydroflavonol reductase, $\left(\mathrm{F} 3^{\prime} \mathrm{H}\right.$ and $\left.\mathrm{F}^{\prime} 5^{\prime} \mathrm{H}\right)$ flavonoid $3^{\prime}$ and $3^{\prime} 5^{\prime}$ hydroxylase, (F3H) flavanone 3-hydroxylase, (FLS) flavonol synthase, (Glc) glucose, (PAL) phenylalanine ammonia lyase, (Rha) rhamnose. 
Spelt et al. 2000; Albert et al. 2011). Specific spatial expression of the $R 2 R 3-M Y B s$ thus determines the production of anthocyanin compounds in only certain floral tissues (Tornielli et al. 2009).

In contrast, $b H L H$ and $W D R$ genes have wider expression profiles and also affect other processes in the plant. In Petunia, AN1 is expressed in pigmented tissues and is required for anthocyanin production, but it also has other functions besides pigmentation that influence vacuolar $\mathrm{pH}$ and morphology of the seed coat (Spelt et al. 2000, 2002). Another $b H L H$ gene, $J A F 13$, also has a role in anthocyanin pigmentation, although its exact role is unclear (Spelt et al. 2000). The WDR gene AN11 is expressed in all tissues, even in those that are nonpigmented (de Vetten et al. 1997). Its role has not been precisely characterized but it also may regulate vacuolar $\mathrm{pH}$, and plants deficient in AN11 have defects in the epidermal cells of seeds and flowers as well as pigmentation loss in both tissues (Quattrocchio 1994; Zenoni et al. 2011). Repressors of anthocyanin production have also been characterized. The R3-MYB transcription factor MYBx is known to repress anthocyanin biosynthesis, possibly by competing with the R2R3-MYBs for the promoters of target genes (Kroon 2004).

The MYB-bHLH-WDR complex comprises the main classes of proteins involved in anthocyanin regulation across all species studied thus far (Koes et al. 2005; Grotewold 2006). Readers are referred to recent reviews for tables of these homologous regulators in different species (Koes et al. 2005; Petroni and Tonelli 2011; Davies et al. 2012). In dicotyledonous plants, the MYB-bHLH-WDR complex up-regulates late anthocyanin biosynthetic genes; however, the starting point of the "late" genes differs among species. In Petunia, $F 3^{\prime} 5^{\prime} H$ is regulated along with DFR and subsequent genes (Brugliera et al. 1999), whereas in Ipomoea, the early biosynthetic genes $C H S$, $\mathrm{CHI}$, and $\mathrm{F} 3 \mathrm{H}$ may be partly regulated by the MYBbHLH-WDR complex but are also independently regulated (Morita et al. 2006). This regulatory separation contrasts with the monocotyledonous plant maize, in which all anthocyanin biosynthetic genes are regulated together by the MYB-bHLH-WDR complex (Mol et al. 1998).

In other species, it is also likely that bHLH and WDR proteins are involved in additional processes unrelated to pigmentation while interacting with R2R3-MYBs that provide specific functions (Koes et al. 2005). In Antirrhinum and Ipomoea, it has also been shown that different MYBs regulate anthocyanin production in specific floral and vegetative tissues (Morita et al. 2006; Schwinn et al. 2006). In Arabidopsis, four highly related R2R3-MYB sequences similarly regulate late anthocyanin biosynthetic genes. These genes are not involved in floral anthocyanin production because Arabidopsis has white flowers and reproduces by self-fertilization; one of these R2R3-MYBs, PAP1, is necessary for anthocyanin production in young seedlings, whereas the function of the other genes is unknown (Gonzalez et al. 2008). This clade of Arabidopsis genes is classified as subfamily 6 of the R2R3-MYB transcription factor family (Stracke et al. 2001). Anthocyanin-implicated R2R3-MYBs from many species, including AN2 from Petunia, show homology with this subfamily (see Fig. 3 in Cooley et al. 2011).

\section{Regulatory and Structural Genes Contribute to Natural Variation in Color}

In the previous two sections, we discussed the major biosynthetic and regulatory genes in anthocyanin production. Natural variation in these genes may form the basis for color differences between species and variants. Most of these genes have been inactivated by mutations in $P$. hybrida. However, for some of these, mutational changes will not only result in shifts in petal color but also affect other pathways and, thereby, may negatively affect overall fitness (Coberly and Rausher 2003). So, which of these genes are likely targets of natural selection during shifts in pollination syndromes? This section gives an overview of the kind of molecular changes that have been attributed to causing color changes in natural populations of plant species. It also considers whether color variants that have arisen and spread in the population could be attributed to pollinator behavior. This information is summarized in Table 1. Examples are given in which a color polymorphism has been linked to a specific gene and the investigators have shown this by transgenic experiments or by genetic studies showing cosegregation of the gene with flower color. Studies of particular interest are discussed in greater detail below.

The first gene shown to be involved in a naturally occurring color transition was the R2R3-MYB transcription factor AN2 (Wijsman 1983; Quattrocchio et al. 1999). As described above, $A N 2$ regulates the later part of the anthocyanin biosynthetic pathway. The gene is active in the purple flowers of $P$. integrifolia but is inactive in the white flowers of P. axillaris (Quattrocchio et al. 1999; Hoballah et al. 2007). The role of $A N 2$ and color in pollinator attraction was shown by transforming a functional AN2 allele into the $P$. axillaris genetic background that produced a $P$. axillaris line with anthocyanin-pigmented flowers. Pollinator choice tests showed that the hawkmoth Manduca sexta (one of $P$. axillaris' natural pollinators) preferred the white $P$. axillaris parent, whereas the bumblebee pollinator Bombus terrestris showed a preference for the transgenic line (Hoballah et al. 2007). This experiment showed that the modification of a single gene can have a major effect on pollinator behavior. The loss of function of $A N 2$, and thus color, has happened multiple times, as shown by different mutations in populations of $P$. axillaris (Hoballah et al. 2007). Although it is debated whether the loss of AN2 function represented the first step in the divergence of these two species (Hoballah et al. 2007; A. LorenzLemke, pers. comm.), the loss of color constitutes a necessary step in the transition from a bee pollination syndrome to a moth pollination syndrome in $P$. axillaris.

The genus Mimulus contains a yellow, carotenoid-colored clade, in which red, anthocyanin-colored flowers are thought to have independently arisen five times (Cooley and Willis 2009). Two of these gains of red color have been elucidated and have each been attributed to a single, 
Table 1. Genetic polymorphisms associated with natural variants in floral anthocyanin-derived color and benzenoid floral volatiles in species that are pollinated by animal pollinators

\begin{tabular}{|c|c|c|c|c|c|c|}
\hline Taxon & $\begin{array}{l}\text { Gene/s } \\
\text { (locus) }\end{array}$ & Gene family & Mutation & Molecular polymorphism & Role in pollinator preference & Reference \\
\hline Antirrhinum & $\begin{array}{l}\text { ROSEA1, } \\
\text { ROSEA2 } \\
\text { (rosea); } \\
\text { VENOSA } \\
(\text { venosa) }\end{array}$ & $\begin{array}{l}R 2 R 3-M Y B \\
\quad \text { (subfamily } \\
\text { 6) }\end{array}$ & $\mathrm{R}$ & $\begin{array}{l}\text { Causal polymorphisms not } \\
\text { yet identified in natural } \\
\text { accessions. Differences in } \\
\text { expression and target } \\
\text { specificity of these genes } \\
\text { contribute to variation in at } \\
\text { least six species of } \\
\text { Antirrhinum. }\end{array}$ & $\begin{array}{l}\text { Field tests with } A \text {. majus } \\
\text { NILs differing in } V E N O S A \\
\text { and ROSEA1 activity } \\
\text { showed that bumblebee } \\
\text { pollinators preferred } \\
\text { flowers with anthocyanin } \\
\text { pigmentation to those } \\
\text { without. } \\
\text { Hybrid zone with yellow- } \\
\text { flowered } A \text {. } m \text {. var. stri- } \\
\text { atum and pink-flowered } \\
\text { A. } m \text {. var. pseudomajus } \\
\text { shows cline in flower color } \\
\text { and genotype of ROSEA1 } \\
\text { indicating selection- } \\
\text { maintaining color differ- } \\
\text { ence. }\end{array}$ & $\begin{array}{l}\text { Schwinn et al. } \\
\text { 2006; Whibley } \\
\text { et al. 2006; } \\
\text { Shang et al. } \\
2011\end{array}$ \\
\hline \multirow[t]{2}{*}{ Iochroma } & $F 3^{\prime} 5^{\prime} H$ & CYP75A & $\mathrm{S}$ & $\begin{array}{l}\text { Deletion of a } F 3^{\prime} 5^{\prime} H \text { gene in } \\
\text { I. gesnerioides compared } \\
\text { to I. cyaneum leads to } \\
\text { pelargonidin-derived } \\
\text { anthocyanins instead of } \\
\text { cyanidin-derived } \\
\text { anthocyanins. }\end{array}$ & $\begin{array}{l}\text { Color is not associated with } \\
\text { selection by functional } \\
\text { pollinator groups. }\end{array}$ & $\begin{array}{l}\text { Smith et al. } \\
\text { 2008; Smith } \\
\text { and Rausher } \\
2011\end{array}$ \\
\hline & $D F R$ & $D F R$ & $\mathrm{~S}$ & $\begin{array}{l}\text { Difference in substrate } \\
\text { specificity between DFR } \\
\text { from I. gesnerioides and } \\
\text { I. cyaneum. }\end{array}$ & & \\
\hline $\begin{array}{l}\text { Ipomoea } \\
\text { purpurea }\end{array}$ & $F 3^{\prime} H(P)$ & CYP75B & $\mathrm{S}$ & $\begin{array}{l}\text { A loss-of-function mutation } \\
\text { in the } F 3^{\prime} H \text { gene causes } p p \\
\text { individuals to be unable to } \\
\text { produce cyanidin-derived } \\
\text { anthocyanins. }\end{array}$ & & $\begin{array}{l}\text { Zufall and } \\
\text { Rausher } 2003\end{array}$ \\
\hline $\begin{array}{l}\text { Ipomoea } \\
\text { purpurea }\end{array}$ & $C H S-D(A)$ & CHS & $\mathrm{S}$ & $\begin{array}{l}\text { A loss-of-function mutation } \\
\text { in the } C H S-D \text { gene causes } \\
\text { a a individuals to be unable } \\
\text { to produce anthocyanins in } \\
\text { flowers and also affects } \\
\text { flavonoid production in } \\
\text { other tissues. }\end{array}$ & $\begin{array}{l}\text { Visitation frequency by } \\
\text { mainly bumblebee pol- } \\
\text { linators to white } a a \\
\text { individuals does not differ } \\
\text { from pigmented } A A \\
\text { individuals. }\end{array}$ & $\begin{array}{l}\text { Coberly and } \\
\text { Rausher 2003; } \\
\text { Fehr and } \\
\text { Rausher } 2004\end{array}$ \\
\hline $\begin{array}{l}\text { Ipomoea } \\
\text { purpurea }\end{array}$ & $\begin{array}{c}I p M Y B 1 \\
(W)\end{array}$ & $\begin{array}{l}R 2 R 3-M Y B \\
\quad \text { (subfamily } \\
6 \text { ) }\end{array}$ & $\mathrm{R}$ & $\begin{array}{l}\text { A loss-of-function mutation } \\
\text { in IpMYBI is correlated } \\
\text { with the down-regulation } \\
\text { of multiple anthocyanin } \\
\text { biosynthetic genes in } w w \\
\text { individuals and loss of } \\
\text { pigmentation. }\end{array}$ & $\begin{array}{l}\text { White-flowered individuals } \\
\text { are visited less by bum- } \\
\text { blebee pollinators when } \\
\text { rare and self at a higher rate } \\
\text { than plants with } \\
\text { pigmented flowers. }\end{array}$ & $\begin{array}{l}\text { Epperson and } \\
\text { Clegg 1987; } \\
\text { Tiffin et al. } \\
\text { 1998; Chang } \\
\text { et al. } 2005\end{array}$ \\
\hline
\end{tabular}

\begin{tabular}{|c|c|c|c|c|}
\hline $\begin{array}{l}\text { Ipomoea } \\
\text { quamoclit }\end{array}$ & $F 3^{\prime} H$ & CYP75B & $\mathrm{R}$ & $\begin{array}{l}\text { Causal polymorphism not } \\
\text { yet identified. A cis-reg- } \\
\text { ulatory change to } F 3^{\prime} H \\
\text { affects expression of the } \\
\text { gene and influences flux } \\
\text { between cyanidin-derived } \\
\text { anthocyanins and pelar- } \\
\text { gonidin-derived } \\
\text { anthocyanins. }\end{array}$ \\
\hline $\begin{array}{l}\text { Mimulus } \\
\quad \text { aurantiacus }\end{array}$ & $M Y B$ & $\begin{array}{l}R 2 R 3-M Y B \\
\text { (subfamily } \\
\text { 6) }\end{array}$ & $\mathrm{R}$ & $\begin{array}{l}\text { Causal polymorphism not } \\
\text { yet identified. A cis- or } \\
\text { trans-regulatory change in } \\
\text { R2R3-MYB influences } \\
\text { color in a complex fashion } \\
\text { in yellow- and red-flow- } \\
\text { ered races of } M \text {. auran- } \\
\text { tiacus. }\end{array}$ \\
\hline
\end{tabular}

Des Marais and Rausher 2010

Selection on color loci maintains geographic differentiation of yellowand red-flowered races, and hawkmoths and hummingbirds show strong preferences for the different races, respectively.
Streisfeld and Kohn 2005, 2007; Streisfeld and Rausher 2009a 
Table 1. (Continued)

\begin{tabular}{|c|c|c|c|c|c|c|}
\hline Taxon & $\begin{array}{l}\text { Gene/s } \\
\text { (locus) }\end{array}$ & Gene family & Mutation & Molecular polymorphism & Role in pollinator preference & Reference \\
\hline $\begin{array}{l}\text { Mimulus } \\
\text { cupreus }\end{array}$ & $\begin{array}{l}\text { McMYB1, } \\
\text { McMYB2, } \\
\text { McMYB3 } \\
\text { (pla1) }\end{array}$ & $\begin{array}{l}R 2 R 3-M Y B \\
\quad \text { (subfamily } \\
\quad 6)\end{array}$ & $\mathrm{R}$ & $\begin{array}{l}\text { Causal polymorphism not } \\
\text { yet identified. The } M \text {. } \\
\text { cupreus plal locus and, in } \\
\text { particular, McMYB2 ex- } \\
\text { pression are correlated } \\
\text { with higher expression of } \\
\text { anthocyanin biosynthetic } \\
\text { genes compared to alleles } \\
\text { from the yellow morph of } \\
\text { M. cupreus. }\end{array}$ & $\begin{array}{l}\text { Pollinator visitation rate by } \\
\text { Bombus dahlbomii to } \\
\text { M. cupreus in the popu- } \\
\text { lation of central Chile was } \\
\text { low compared to other } \\
\text { Mimulus species at the } \\
\text { same study site. Discrim- } \\
\text { ination was not associated } \\
\text { with flower color. Popu- } \\
\text { lation at this site is thought } \\
\text { to be maintained by } \\
\text { selfing. }\end{array}$ & $\begin{array}{l}\text { Cooley et al. } \\
2008,2011\end{array}$ \\
\hline $\begin{array}{l}\text { Mimulus } \\
\text { luteus }\end{array}$ & $\begin{array}{l}\text { MvMYB4, } \\
\text { MvMYB5 } \\
\text { (pla2) }\end{array}$ & $\begin{array}{l}R 2 R 3-M Y B \\
\text { (subfamily } \\
\text { 6) }\end{array}$ & $\mathrm{R}$ & $\begin{array}{l}\text { Causal polymorphism not } \\
\text { yet identified. The } M . l \text {. } \\
\text { variegatus allele of } \\
M v M Y B 5 \text { correlated with } \\
\text { higher expression of an- } \\
\text { thocyanin biosynthetic } \\
\text { genes compared to the } \\
\text { allele from yellow } M l \text {. } \\
\text { luteus. }\end{array}$ & $\begin{array}{l}\text { Pollinator visitation by } \\
\text { single, generalist pol- } \\
\text { linator in the population in } \\
\text { central Chile did not show } \\
\text { discrimination between } \\
\text { red } M . l \text {. variegatus and } \\
\text { yellow } M \text {. l. luteus. Some } \\
\text { assortative mating may } \\
\text { occur owing to preferences } \\
\text { of individual pollinators. }\end{array}$ & $\begin{array}{l}\text { Cooley et al. } \\
2008,2011\end{array}$ \\
\hline Petunia & $A N 2$ & $\begin{array}{l}R 2 R 3-M Y B \\
\text { (subfamily } \\
\text { 6) }\end{array}$ & $\mathrm{R}$ & $\begin{array}{l}\text { Functional gene regulates } \\
\text { production of antho- } \\
\text { cyanins in the corolla of } \\
P \text {. integrifolia. At least five } \\
\text { independent loss-of-func- } \\
\text { tion mutations in the cod- } \\
\text { ing region contribute to } \\
\text { down-regulation of antho- } \\
\text { cyanin biosynthetic genes } \\
\text { in the corolla of } P \text {. } \\
\text { axillaris. }\end{array}$ & $\begin{array}{l}\text { Introduction of functional } \\
\text { AN2 into white } P \text {. axillaris } \\
\text { partially restored antho- } \\
\text { cyanin production. The } \\
\text { pigmented, transgenic line } \\
\text { showed fourfold less feed- } \\
\text { ings by Manduca sexta and } \\
\text { threefold more visits by } \\
\text { Bombus terrestris com- } \\
\text { pared to wild type in pol- } \\
\text { linator-choice assays in } \\
\text { controlled conditions. }\end{array}$ & $\begin{array}{l}\text { Quattrocchio } \\
\text { et al. 1999; } \\
\text { Hoballah et al. } \\
2007\end{array}$ \\
\hline Petunia & $O D O 1$ & $\begin{array}{l}R 2 R 3-M Y B \\
\text { (subfamily } \\
\text { undefined) }\end{array}$ & $\mathrm{R}$ & $\begin{array}{l}\text { Causal polymorphisms not } \\
\text { yet identified. A cis- } \\
\text { regulatory change is } \\
\text { suggested to cause ex- } \\
\text { pression differences. }\end{array}$ & $\begin{array}{l}\text { NILs that differed only in } \\
\text { floral scent production } \\
\text { were bred into the genetic } \\
\text { backgrounds of } P \text {. axillaris } \\
\text { and } P \text {. exserta. Manduca } \\
\text { sexta moths showed a } \\
\text { significant preference for } \\
\text { scented lines over non- } \\
\text { scented lines. No prefer- } \\
\text { ence was displayed when } \\
\text { confronted with conflict- } \\
\text { ing visual and olfactory } \\
\text { cues. }\end{array}$ & $\begin{array}{l}\text { Klahre et al. } \\
2011\end{array}$ \\
\hline \multirow[t]{2}{*}{$\begin{array}{l}\text { Phlox } \\
\quad \text { drummondii }\end{array}$} & $M Y B$ & $\begin{array}{l}R 2 R 3-M Y B \\
\quad \text { (subfamily } \\
\text { 6) }\end{array}$ & $\mathrm{R}$ & $\begin{array}{l}\text { Causal polymorphisms not } \\
\text { yet identified. A cis-reg- } \\
\text { ulatory change affects ex- } \\
\text { pression of the MYB, } \\
\text { which is correlated with } \\
\text { the expression level of } \\
\text { anthocyanin biosynthetic } \\
\text { genes. }\end{array}$ & $\begin{array}{l}\text { Sympatric populations of } \\
P . \text { drummondii with } \\
P . \text { cuspidata show dark red } \\
\text { flower color; allopatric } \\
\text { populations are light blue. } \\
\text { Common garden-field } \\
\text { experiment showed re- } \\
\text { duced hybridization be- } \\
\text { tween light- and dark- } \\
\text { colored plants caused by } \\
\text { color-intensity constancy } \\
\text { by pollinators. }\end{array}$ & \multirow[t]{2}{*}{$\begin{array}{l}\text { Hopkins and } \\
\text { Rausher 2011, } \\
2012 \text {; } \\
\text { Hopkins et al. } \\
2011\end{array}$} \\
\hline & $F 3^{\prime} 5^{\prime} H$ & $C Y P 75 A$ & $\mathrm{R}$ & $\begin{array}{l}\text { A cis-regulatory change } \\
\text { affects expression of } \\
F 3^{\prime} 5^{\prime} H \text { and influences } \\
\text { color hue. }\end{array}$ & $\begin{array}{l}\text { No evidence for discrim- } \\
\text { ination by color hue, } \\
\text { despite previous study } \\
\text { showing selection on the } \\
\text { "red" allele. }\end{array}$ & \\
\hline
\end{tabular}

The Mutation column refers to the type of mutation that has occurred: either affecting the coding region of a structural (S) gene or affecting regulatory (R) sequences (either a cis-regulatory element or the coding sequence of a transcription factor). Where available, information has been included about the role of the genetic polymorphism in pollinator preference and/or selection by pollinators.

(AN2) Anthocyanin2, (CHS) chalcone synthase, (CYP) cytochrome P450 monooxygenase, (DFR) dihydroflavonol reductase, (F3' $\mathrm{H}$ and $\left.\mathrm{F}^{\prime} 5^{\prime} \mathrm{H}\right)$ flavonoid $3^{\prime}$ and $3^{\prime} 5^{\prime}$ hydroxylase, (NIL) near isogenic line, (ODO1) odorant1. 
dominant gain-of-function mutation in loci containing R2R3-MYBs of subfamily 6. The locus, petal lobe anthocyanin 1 (pla1), is associated with red color in the species $M$. cupreus, whereas the locus pla 2 produces red pigmentation in $M$. luteus variegatus (Cooley and Willis 2009; Cooley et al. 2011).

The plal locus may also be associated with the production of anthocyanin-pigmented corolla banding and calyx spotting in M. guttatus (Lowry et al. 2012). Each locus contains duplicated homologous R2R3-MYBs and the loci themselves are likely to be related by a previous duplication event (Cooley et al. 2011). For both loci, it was shown that the level of anthocyanins is correlated with the coordinate up-regulation of both early and late anthocyanin biosynthetic genes, indicating that the R2R3MYBs function as regulators of the anthocyanin pathway (albeit there may be some differences to other dicotyledonous species). The exact role of each R2R3-MYB in influencing the difference in color between the yellow ancestors and derived red species has not yet been elucidated. However, this example of parallel evolution shows the central role of R2R3-MYB factors in determining color differences in Mimulus. Similarly, two trans-acting regulatory loci are implicated in determining color differences between parapatrically distributed red- and yellowflowered races of $M$. aurantiacus, a species from a separate Mimulus clade (Streisfeld and Rausher 2009a). These races are likely under selection by their hawkmoth and hummingbird pollinators who show strong preferences for flower color (Streisfeld and Kohn 2007). Conversely, little evidence was found to suggest that flower color in M. cupreus, M. l. variegatus, and a yellow-flowered species M. l. luteus influences pollinator behavior (Cooley et al. 2008). An alternative explanation for the occurrence of red-flowered species is that selection on other traits has caused anthocyanin pigmentation to arise and it may be a pleiotropic effect of the biosynthetic pathways controlling pigmentation (Cooley and Willis 2009).

A member of the R2R3-MYB subfamily 6 has also been shown to be responsible for a gain in red color in Phlox. In this example, the change in the $R 2 R 3-M Y B$ works in concert with a cis-regulatory change to the $F 3^{\prime} 5^{\prime} H$ gene. Phlox drummondii has light blue flowers similar to another species, $P$. cuspidata. Where these species are found in sympatry, $P$. drummondii produces red flowers. The level of anthocyanins produced by the red flowered $P$. drummondii is higher than that in $P$. cuspidata, and this is correlated with a higher expression of $R 2 R 3-M Y B$ in $P$. drummondii (Hopkins and Rausher 2011). The up-regulation of R2R3-MYB is caused by an as-yet-unidentified change in a cis-regulatory element of the $P$. drummondii allele. The change in hue is attributed also to a cis-regulatory difference acting on $F 3^{\prime} 5^{\prime} H$, meaning that flux in the pathway is redirected from the malvidin branch of the pathway to the cyanidin branch (Hopkins and Rausher 2011). Field experiments showed that the "color intensity" $R 2 R 3-M Y B$ locus maintains reproductive isolation of the red-flowered $P$. drummondii from $P$. cuspidata by decreasing interspecific pollen flow. Surprisingly, the $F 3^{\prime} 5^{\prime} H$ locus affecting hue does not seem to be important, with current knowledge, for maintaining the species (Hopkins and Rausher 2012), despite the previous finding of a selective sweep on the allele causing red color (Hopkins et al. 2011). This highlights the necessity to compare population genetics studies with tests of pollinator preference and fitness differences in the field.

In Ipomoea, a different mechanism has been shown to be responsible for the production of red, bird pollinated flowers. The ancestral color state is believed to be blue-purple flowers which are pollinated by bees, with red-flowered hummingbird pollinated species having arisen four times independently (Streisfeld and Rausher 2009b). Ipomoea quamoclit represents one member of a clade of red-flowered species. In this species, Des Marais and Rausher (2010) showed that downregulation of the biosynthetic gene, $F 3^{\prime} H$, at least partly as a result of mutation in a cisregulatory element, resulted in flux in the pathway being directed from cyanidin-derived anthocyanins to pelargonidin-derived anthocyanins. This regulation is tissue-specific, occurring in the floral tissue but not in the vegetative tissue. The investigators speculate that this change characterizes the other species in the I. quamoclit clade, and that it is similar to what has occurred in another red-flowered lineage of Ipomoea, I. horsfalliae. In this species, $F 3^{\prime} H$ is also downregulated, but the causal mechanism has not been found (Streisfeld and Rausher 2009b). The investigators postulate that $F 3^{\prime} H$ could be a common target of mutations to transition from bee pollination to hummingbird pollination; many red-flowered angiosperm species which have gone through a transition from blue-purple flowers are colored by pelargonidin-derived anthocyanins (Rausher 2008; Streisfeld and Rausher 2009b). It remains to be established whether the transition to red flowers in Ipomoea is as a result of selection from pollinators.

In all the above examples, color changes have involved changes to the regulation of the anthocyanin pathwayeither regulatory genes (trans-regulatory changes) or the targets of regulatory genes, regulatory elements (cis-regulatory changes). However, examples of changes to color caused by mutations in structural genes are also present. The common morning glory Ipomoea purpurea has populations that are highly polymorphic for color. All of these polymorphisms have been attributed to variation in four loci (Epperson and Clegg 1988). The genetic basis for three of these loci has been elucidated and two of them result from mutations to biosynthetic genes. For the $P$ locus, a mutation in the coding region of the $F 3^{\prime} H$ gene produces a truncated protein that cannot use dihydroquercetin and, thus, cannot produce cyanidin-derived anthocyanins (Zufall and Rausher 2003). Flux is redirected from the cyanidin branch of the biosynthetic pathway to the pelargonidin branch, thereby producing red flowers in a similar way as to that described for I. quamoclit. The $A$ locus produces a class of white-colored variants of I. purpurea that cannot produce anthocyanins owing to a transposon insertion in the CHS-D gene (Johzuka-Hisatomi et al. 1999). This loss-of-function mutation in the $C H S-D$ gene means that neither anthocyanins nor other flavonoid compounds can be produced throughout the whole plant. These mutants show decreased fitness and 
this is likely attributable to a deficiency in flavonoid compounds that function to ameliorate heat stress (Coberly and Rausher 2003). The third locus represents a regulatory change controlled by IpMYB1, another member of the $R 2 R 3-M Y B$ subfamily 6 , and is also responsible for producing a class of white-flowered variants (Chang et al. 2005). In this example, white-flowered variants do not appear to be under selection by pollinators (for review, see Clegg and Durbin 2003).

\section{The Role of Ultraviolet Color May Be Linked to Anthocyanin Pigmentation}

Insects, pollinating birds, and bats have photoreceptors for UV light (Menzel and Backhaus 1991; Winter et al. 2003; Herrera et al. 2008), and many flowering plants absorb in the UV. UV-absorbing nectar guides that help to orient insects with regard to the source of nectar have been known for some time (Daumer 1958; Jones and Buchmann 1974; Penny 1983). Recent work in Mimulus has shown that UV-absorbing petals can be important for the attraction of bees and other pollinators in a natural habitat and also reaffirmed that these petals can be important for bee orientation (Rae and Vamosi 2012).

UV-absorbing floral pigments may be useful for detection of flowers by night-active insects. Night-active hawkmoths generally visit white-flowered plants, such as Petunia axillaris. These flowers' maximal reflectance seems optimal for the flower to be perceived at low-light intensity. However, most white flowers absorb UV light and, thus, do not reflect all wavelengths perceived by the insect's photoreceptors and do not take advantage of all available photons (Kevan et al. 1996). Interestingly, hawkmoths have been shown to display true color vision at light intensities as low as dim starlight (Kelber et al. 2002). Therefore, hawkmoths probably use color vision to detect UV-absorbing flowers against a background of "dull" foliage that reflects to a low degree across all wavelengths (Kevan et al. 1996).

In Petunia, flavonols are the main pigments contributing to the UV absorbance of the flower. The absence of anthocyanins and the presence of flavonols in the $P$. axillaris flower may be attributable to selection by hawkmoths, but alternative roles of flavonols in plant defense against pathogens or abiotic stresses should also be considered (Gould and Lister 2005). Another possibility is that the presence of flavonols is a consequence of selection for loss of anthocyanin biosynthesis, because down-regulation of $D F R$ would redirect metabolic flux toward FLS and flavonol biosynthesis (Fig. 1). Molecular genetics in combination with behavioral experiments can test such hypotheses.

\section{FLORAL SCENT}

\section{Floral Volatiles Act as Species-Specific Long- Distance Signals to Attract Pollinators}

Floral scent bouquets may consist of as many as 20-60 different volatiles (Knudsen et al. 2006), synthesized from diverse primary metabolites (Dudareva et al. 2006). Most floral volatiles belong to fatty acid derivatives, terpenoids, or benzenoids. The number and concentration of compounds provide species-specific olfactory cues (Raguso et al. 2003; Hoballah et al. 2005; Raguso 2008), and the combination with visual stimuli allows searching pollinators to use different sensory channels to identify target flowers.

Bats, bees, butterflies, hummingbirds, and moths are able to sense floral scents and have been shown to discriminate among odor differences (von Helversen et al. 2000; Kunze and Gumbert 2001; Wright et al. 2002, 2005; Ômura and Honda 2005; Kessler et al. 2008; Zvi et al. 2012). Recently, it was shown that the hawkmoth Manduca sexta processes olfactory stimuli through two olfactory channels, allowing it to coordinate an innate preference with olfactory learning (Riffell et al. 2012). Hawkmoths use odor cues to locate target plants over long distances (Raguso and Willis 2002a), which may explain the high odor emission rates in flowers displaying moth-pollination syndromes. For instance, moth-pollinated Clarkia breweri flowers emit strong floral scents compared to flowers of the closely related bee-pollinated C. concinna (Raguso and Pichersky 1995). However, the importance of olfactory and visual stimuli for the attraction of specific pollinator guilds differs (Raguso and Willis 2005; Goyret et al. 2007; Klahre et al. 2011).

\section{The Biosynthesis of Volatile Benzenoid Compounds}

Petunia x hybrida cv Mitchell is a popular model system to elucidate the biosynthesis of floral volatile benzenoids, and many of the structural and regulatory genes have been identified in Petunia. For other odor compounds, the reader can refer to excellent reviews of Pichersky and Gershenzon 2002; Dudareva et al. 2006.

Phenylalanine-derived volatiles come in three groups that are identified by the number of carbon atoms in their side chains (Fig. 4; all volatile benzenoid compounds are highlighted in purple). In the $\mathrm{C}_{6}-\mathrm{C}_{2}$ group, the key enzyme phenylacetaldehyde synthase (PAAS) catalyzes the decarboxylation of phenylalanine to phenylacetaldehyde, which can subsequently be reduced, oxidized, or esterified.

The $\mathrm{C}_{6}-\mathrm{C}_{3}$ and $\mathrm{C}_{6}-\mathrm{C}_{1}$ pathways both start from transcinnamic acid, which is synthesized from phenylalanine by the activity of phenylalanine ammonia lyase (PAL). Entry into the $\mathrm{C}_{6}-\mathrm{C}_{1}$ pathway requires shortening of the $\mathrm{C}_{3}$ side chain of trans-cinnamic acid by two carbons, which can occur via both a CoA-dependent $\beta$-oxidative pathway analogous to the catabolism of fatty acids (Hertweck et al. 2001; Moerkercke et al. 2009; Klempien et al. 2012; Qualley et al. 2012) and a CoA-independent non- $\beta$-oxidative pathway (Boatright et al. 2004; Orlova et al. 2006).

The conversion of trans-cinnamic acid into $p$-coumaric acid leads into the $\mathrm{C}_{6}-\mathrm{C}_{3}$ branch. The specific reaction that gives rise to coniferyl alcohol is as-yet unknown. 


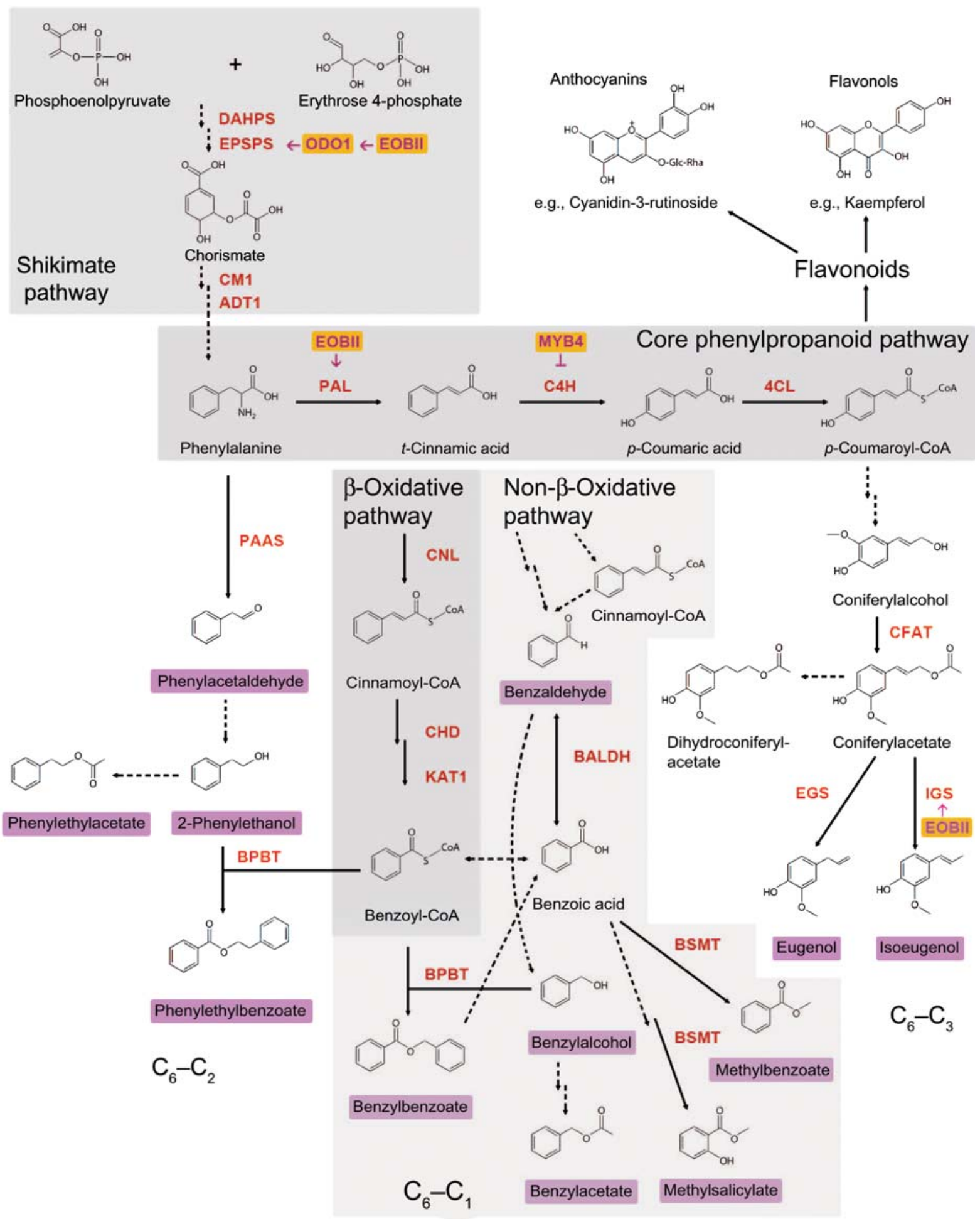

Figure 4. The benzenoid pathway leading to the production of volatile compounds in scented Petunia. Volatile compounds emitted by scented Petunia are highlighted in purple. Enzymes shown in red indicate known steps in Petunia; unknown enzymatic steps are indicated by dashed arrows. Multiple dashed arrows indicate multiple unknown steps. Transcriptional regulators are highlighted in yellow. (4CL) 4-Coumarate CoA-ligase, (ADT) arogenate dehydratase, (BALDH) benzaldehyde dehydrogenase, (BSMT) (S-adenosyl-L-methionine) benzoic acid/salicylic acid carboxyl methyltransferase, (BPBT) benzoyl-CoA:benzylalcohol/2-phenylethanol benzoyltransferase, $(\mathrm{C} 4 \mathrm{H})$ cinnamate 4-hydroxylase, (CFAT) coniferyl alcohol acyltransferase, (CHD) cinnamoyl-CoA hydratasedehydrogenase, (CM) chorismate mutase, (CNL) cinnamate CoA-ligase, (DAHPS) 3-deoxy-D-arabino-heptulosonate-7-phosphate synthase, (EGS) eugenol synthase, (EPSPS) 5-enolpyruvylshikimate-3-phosphate synthase, (IGS) isoeugenol synthase, (KAT1) 3ketoacyl-CoA thiolase, (PAAS) phenylacetaldehyde synthase, (PAL) phenylalanine ammonia lyase. 
Coniferyl alcohol acyltransferase (CFAT) acetylates coniferyl alcohol to produce coniferyl acetate. This serves as the substrate for isoeugenol synthase (IGS) and eugenol synthase (EGS), which catalyze the formation of isoeugenol and eugenol, respectively (Clark 2009). Some $P$. axillaris emit neither eugenol nor isoeugenol but produce high levels of dihydroconiferyl acetate. In P. a. parodii S7, EGS is functional, but the gene encoding IGS contains a frameshift mutation leading to its inactivity. Unexpectedly, this does not lead to higher eugenol levels (Koeduka et al. 2009).

Because all benzenoid volatiles derive from phenylalanine, substrate competition may regulate the fluxes through the $\mathrm{C}_{6}-\mathrm{C}_{2}, \mathrm{C}_{6}-\mathrm{C}_{1}$, and $\mathrm{C}_{6}-\mathrm{C}_{3}$ pathways. Such substrate competition may be determined by the relative abundance and enzymatic properties of the branch-specific enzymes. Indeed, there is evidence that a higher affinity for phenylalanine by PAL compared to PAAS causes a higher flux through the $\mathrm{C}_{6}-\mathrm{C}_{1}$ and $\mathrm{C}_{6}-\mathrm{C}_{3}$ branches of the pathway (Maeda et al. 2010).

\section{The Regulation of Floral Scent Production}

The emission of floral volatile benzenoids from the epidermal cells of $P$. axillaris and $P$. hybrida cv Mitchell petals begins at anthesis and ceases after pollination (Negre et al. 2003; Underwood et al. 2005). Emission follows a circadian rhythm that peaks at dusk (Verdonk et al. 2005; Clark 2009). Together, this indicates precise spatial (Van Moerkercke et al. 2012), developmental, and temporal regulation of the pathway. So far, three transcriptional regulators of scent production, ODORANT1 (ODO1), EMISSION OF BENZENOIDS II (EOBII), and PhMYB4, have been identified. Expression of the R2R3$M Y B O D O 1$ peaks before the onset of volatile emission and its transcript levels are low the next morning. ODO1 activates the promoter of the gene encoding EPSPS, an enzyme of the shikimate pathway, suggesting that ODO1 is involved in the petal-specific up-regulation of phenylalanine as the precursor for volatile production (Verdonk et al. 2005). Accordingly, down-regulation of $O D O 1$ in transgenic $P$. hybrida cv Mitchell plants strongly reduced benzenoid emission (Verdonk et al. 2005). The expression levels of genes encoding DAHPS, EPSPS, PAL, and $\mathrm{CM}$ were decreased, but, interestingly, the late-acting genes encoding BSMT and BPBT were up-regulated. Expression of the structural genes BSMT, BPBT, together with PAAS and IGS, precedes volatile emission and has been detected at high levels during the light period and low levels during the dark period (Colquhoun et al. 2010). However, the rhythmic transcript accumulation of at least $B S M T$ and $P A A S$ seems not to cause the rhythmic emission of the floral volatiles, based on constant activities detected over a 24-h period (Kolosova et al. 2001). Instead, oscillations of early precursor pools and $O D O 1$ expression have been suggested to control the rhythmic emission of floral fragrance.

The second R2R3-MYB transcription factor, EOBII, binds to a specific MYB-binding site located in an upstream enhancer region to activate the expression of ODO1 (Van Moerkercke et al. 2011). EOBII also activates $P A L$ and $I G S$ promoters (Spitzer-Rimon et al. 2010). Silencing of EOBII down-regulates $O D O 1$ and genes of the shikimate and phenylpropanoid pathways. As with $O D O 1$, it has a rhythmic expression pattern, but the transcript levels peak in the early morning hours and are lowest during the late afternoon. The difference in phasing of the $O D O 1$ and EOBII rhythms might be explained by time-delayed activation of $O D O 1$ expression. But $E O B I I$ is expressed in early flower development when $O D O 1$ is not. Functional analyses of $O D O 1$ promoter fragments have provided evidence that at least one additional factor is needed for high $O D O 1$ promoter activity (Van Moerkercke et al. 2012). This as-yet-unidentified factor might partly explain the interaction of $E O B I I$ and $O D O 1$ despite their different expression patterns and the finding that overexpression of EOBII did not result in significant higher ODO1 levels (Spitzer-Rimon et al. 2010).

The third identified transcription factor, PhMYB4, is also an R2R3-MYB transcription factor. It negatively regulates $\mathrm{C} 4 \mathrm{H}$ (Colquhoun and Clark 2011; Colquhoun et al. 2011), indirectly controlling the emission of isoeugenol and eugenol by precursor supply. It was hypothesized to "fine-tune" the bouquet of floral fragrance by affecting the balance between the $\mathrm{C}_{6}-\mathrm{C}_{1}$ and $\mathrm{C}_{6}-\mathrm{C}_{3}$ branches of the pathway.

\section{Interaction Between Color and Scent at the Biochemical Level}

Interaction between the branches of the benzenoid and flavonoid pathways might occur owing to pleiotropic regulation or to metabolic competition for the common precursor, phenylalanine. Redirection of metabolic flux from one branch to the other has been shown in Dianthus caryophyllus (Zuker et al. 2002). These investigators showed that suppression of $F 3^{\prime} H$ led to white-flowered mutants that produced higher amounts of methylbenzoate compared to colored control plants. In contrast, the introduction of the Arabidopsis R2R3-MYB transcription factor PRODUCTION OF ANTHOCYANIN PIGMENT 1 (PAP1; a member of the R2R3-MYB subfamily 6) into $P$. hybrida enhanced both branches of the phenylpropanoid pathway, leading to the production of color and scent. This argues against metabolic competition but supports the notion that PAP1 has a pleiotropic effect on both pathways (Zvi et al. 2006, 2008). Similarly, 35S:PAP1 transgenic Rosa hybrida showed increased pigmentation as well as eugenol accumulation (Zvi et al. 2012). A more general argument against metabolic competition is the temporal separation of the two pathways. Flavonoids are produced during growth and development of the flower, whereas benzenoids are only produced when the flowers open (Verdonk et al. 2005).

However, multiple examples contradict the idea of a pleiotropic regulator of scent and color. The introduction of the key regulator of anthocyanin biosynthesis, AN2, 
into $P$. axillaris altered flower color but had no effect on scent production (Hoballah et al. 2007), suggesting that this Petunia PAP1 homolog has no effect on volatile emission. Silencing $O D O 1$ and thus decreasing shikimate precursor compounds for benzenoid production did not lead to decreased flavonoid production (Verdonk et al. 2005). In addition, EOBII expression in transgenic Nicotiana tabacum increased PAL transcript levels but $C H S$ and $F 3^{\prime} H$ expression levels and anthocyanin levels were not affected (Spitzer-Rimon et al. 2010). Because pleiotropic effects have been observed when foreign transgenes were expressed from a strong viral promoter, the evidence in favor of regulatory interactions between the two pathways should be interpreted with caution.

\section{Behavioral Experiments Test the Importance of Color and Scent in Pollinator Attraction}

Classical behavioral studies have tried to disentangle the importance of olfactory and visual stimuli for pollinator attraction using artificial flowers and cues (Raguso and Willis 2002b; Balkenius and Kelber 2006; Balkenius et al. 2006; Goyret et al. 2007). To disentangle visual and olfactory cues in complex flowers, Hirota et al. (2012) generated $\mathrm{F}_{1}$ and $\mathrm{F}_{2}$ hybrids between the butterfly-pollinated daylily and the hawkmoth-pollinated nightlily, each differing in floral color and scent. In an $\mathrm{F}_{2}$ progeny, segregating for both floral traits, neither butterflies nor hawkmoths showed significant preferences for overall scent emission. However, butterflies preferentially visited red- or orange-colored flowers, resembling the daylily color phenotype, whereas moths preferred the yellowcolored flowers, representing the nightlily color phenotype. Thus, the visual stimuli were more important for pollinator attraction. It should be noted, however, that additional floral traits might have been segregating in a $\mathrm{F}_{2}$ population that were not considered in this study.

In Petunia, we set out to construct near isogenic lines (NILs) through repeated backcrossing of hybrids among species with different pollination syndromes. The aim was to obtain plants that differ genetically only in single relevant loci, and phenotypically only in single traits, for instance, petal color or scent production. This makes it possible to dissect the interactions between visual and olfactory stimuli in complex flowers. Such plants can be studied under controlled conditions but can also be introduced into the natural habitats. They can thus be exposed to the variety of natural pollinators visiting during the season, and fitness across generations can be determined. In addition, NILs are attractive genetic material for the isolation of the genes underlying shifts in pollination syndromes.

Using this approach, we crossed the red-flowered, nonscented $P$. exserta with the white, scented $P$. axillaris and mapped two major QTL for scent production in the $F_{2}$ population to chromosomes II and VII. The scent QTL on chromosome VII covered the position of ODO1 (Stuurman et al. 2004; Klahre et al. 2011). ODO1 is highly expressed in $P$. axillaris but is present at low levels in $P$. exserta. In the $\mathrm{F}_{1}$ hybrid, most of the $O D O 1$ transcript was produced from the $P$. axillaris allele, indicating that the difference in expression level of the two alleles is a cis-acting effect (Klahre et al. 2011). The actual polymorphism, potentially a sequence change in the $O D O 1$ promoter, has not yet been determined. The gene(s) underlying the chromosome II QTL are presently unknown. However, repeated backcrossing resulted in an unscented $P$. axillaris NIL as well as a scented $P$. exserta NIL and made it possible to study hawkmoth attraction to scent in otherwise undistinguishable genetic backgrounds. Both in the $P$. axillaris and $P$. exserta backgrounds, the moths had a strong preference for the scented lines over the nonscented lines. Interestingly, when the insects were given the choice between the red, scented $P$. exserta NIL and the white, nonscented $P$. axillaris NIL, a situation in which they had to choose between conflicting visual and olfactory cues, they displayed no preference. This suggests that, at least under the artificial conditions of a wind tunnel experiment, color and scent appear to be equivalent cues (Klahre et al. 2011).

\section{CONCLUSIONS}

Pollination syndromes consist of specific traits, such as floral color, scent, floral morphology, and nectar volume and composition. The correlation between floral traits and pollinator classes across the angiosperms suggests that this convergent evolution is driven by pollinator-mediated selection (Fenster et al. 2004). However, other contributing factors must also be considered. Rausher (2008) discusses this in depth, pointing out that the few examples investigated thus far show selection on color changes but that the selective agent cannot necessarily be attributed to pollinators.

To attract a new pollinator, coordinated changes in multiple traits are required. This raises important questions about the presumably complex molecular genetics of shifts in pollination syndromes. This review focuses on the molecular basis of the pollination syndrome traits, color and scent. For both traits, substantial knowledge has been acquired about the biochemical pathways and transcriptional regulators. A central question in the ecology and evolution of pollination syndromes is which of the trait-determining genes were selected in nature to achieve a shift in pollinator attraction. Altogether, how many genes were involved and how did they change in a coordinated fashion? For color and scent, both structural and regulatory genes contribute to major phenotypic changes, although more regulatory changes are represented in the limited number of examples found so far (Table 1). Genes of small effect would in most cases have escaped detection, but the fact that major genes were found at all is of great significance to the debate about the role of major mutations in adaptive evolution (Bradshaw and Schemske 2003).

The first transcription factor involved in natural variation in petal color was AN2 and $R 2 R 3-M Y B$ s are the only regulatory genes represented so far (Table 1). Subsequent discovery of genes underlying natural variation has relied on candidate gene approaches that are inevitably biased 
toward $R 2 R 3-M Y B$ s. We note that no genes causing natural variation in pollination syndromes have yet been identified de novo. Changes consist of alterations in the coding region of the R2R3-MYBs themselves or changes in cis-regulatory elements. Other regulatory changes concern putative cis changes or changes to the coding sequences of biosynthetic genes, for instance, $F 3^{\prime} H$ or $F 3^{\prime} 5^{\prime} H$ genes. Such changes have effects on the types of anthocyanins produced by adjusting flux through branches of the biosynthetic pathways. Duplication also had a role in the diversification of color, with many of the described examples involving duplication of R2R3-MYBs. Duplication is thought to be a significant factor influencing phenotypic novelty in plants (Flagel and Wendel 2009).

R2R3-MYBs are also involved in the regulation of volatile benzenoid biosynthesis. The R2R3-MYBs EOBII and ODO1 regulate scent biosynthesis in different species and there is evidence that $O D O 1$ underlies natural variation in scent production. However, both $O D O 1$ and $E O B I I$ primarily affect early steps in the pathway and alterations to these genes might be expected to have pleiotropic effects. It seems likely, therefore, that additional regulators of natural variation in scent remain to be discovered.

Coordinated changes in multiple traits could be brought about by genetic changes in master genes that affect multiple traits or by genetic linkage of multiple regulators. There is little convincing evidence thus far for the involvement of coregulation of scent and color in natural variants despite regulators being found that influence early, shared steps of the phenylpropanoid pathway. Linkage of genes in the genome may have occurred in Mimulus and Aquilegia (Bradshaw et al. 1995; Hodges et al. 2002), but much more detailed genetic and physical maps, as well as a better understanding of the genetic and biochemical basis of the traits, will be necessary to address this issue.

Undoubtedly, the rapid advances in whole-genome sequencing will accelerate the identification of the genes that cause natural variation. Functional analysis of such genes, at the level of the gene, trait, and population, will provide new insight not only into plant-pollinator interactions but also in reproductive isolation and ultimately speciation.

\section{ACKNOWLEDGMENTS}

We thank Sarah Robinson, Korinna Esfeld, Arne Jungwirth, and Ulrich Klahre for critically reading the manuscript and for insightful comments; Roman Köpfli for expert assistance with illustrations; and Alexandre Dell'Olivo for photography. This work was supported by grants from the National Centre for Competence in Research "Plant Survival," the Swiss National Science Foundation, and the University of Bern.

\section{REFERENCES}

Albert NW, Lewis DH, Zhang H, Schwinn KE, Jameson PE, Davies KM. 2011. Members of an R2R3-MYB transcription factor family in Petunia are developmentally and environmentally regulated to control complex floral and vegetative pigmentation patterning. Plant J 65: 771-784.

Ando T, Saito N, Tatsuzawa F, Kakefuda T, Yamakage K, Ohtani E, Koshi-ishi M, Matsusake Y, Kokubun H, Watanabe $\mathrm{H}$, et al. 1999. Floral anthocyanins in wild taxa of Petunia (Solanaceae). Biochem Syst Ecol 27: 623-650.

Balkenius A, Kelber A. 2006. Color preferences influences odor learning in the hawkmoth, Macroglossum stellatarum. Naturwissenschaften 93: 255-258.

Balkenius A, Rosén W, Kelber A. 2006. The relative importance of olfaction and vision in a diurnal and a nocturnal hawkmoth. J Comp Physiol A 192: 431-437.

Beld M, Martin C, Huits H, Stuitje AR, Gerats AGM. 1989. Flavonoid synthesis in Petunia hybrida: Partial characterization of dihydroflavonol-4-reductase genes. Plant Mol Biol 13: 491-502.

Bené F. 1941. Experiments on the color preference of blackchinned hummingbirds. Condor 43: 237-242.

Boatright J, Negre F, Chen X, Kish CM, Wood B, Peel G, Orlova I, Gang D, Rhodes D, Dudareva N. 2004. Understanding in vivo benzenoid metabolism in Petunia petal tissue. Plant Physiol 135: 1993-2011.

Bradshaw HD, Schemske DW. 2003. Allele substitution at a flower color locus produces a pollinator shift in monkeyflowers. Nature 426: 176-178.

Bradshaw HD, Wilbert SM, Otto KG, Schemske DW. 1995. Genetic mapping of floral traits associated with reproductive isolation in monkeyflowers (Mimulus). Nature 376: 762-765.

Bradshaw HD, Otto KG, Frewen BE, McKay JK, Schemske DW. 1998. Quantitative trait loci affecting differences in floral morphology between two species of monkeyflower (Mimulus). Genetics 149: 367-382.

Brugliera F, Barri-Rewell G, Holton TA, Mason JG. 1999. Isolation and characterization of a flavonoid 3 '-hydroxylase cDNA clone corresponding to the Ht1 locus of Petunia hybrida. Plant J 19: 441-451.

Chang S-M, Lu Y, Rausher MD. 2005. Neutral evolution of the nonbinding region of the anthocyanin regulatory gene IpMYB1 in Ipomoea. Genetics 170: 1967-1978.

Chittka L, Menzel R. 1992. The evolutionary adaptation of flower colors and the insect pollinators' color vision. J Comp Physiol A 171: 171-181.

Chittka L, Raine NE. 2006. Recognition of flowers by pollinators. Curr Opin Plant Biol 9: 428-435.

Clark DG. 2009. Benzenoids dominate the fragrance of Petunia flowers. In Petunia: Evolutionary, developmental and physiological genetics (ed. Gerats T, Strommer J), pp. 51-70. Springer, New York.

Clegg MT, Durbin ML. 2003. Tracing floral adaptations from ecology to molecules. Nat Rev Genet 4: 206-215.

Coberly LC, Rausher MD. 2003. Analysis of a chalcone synthase mutant in Ipomoea purpurea reveals a novel function for flavonoids: Amelioration of heat stress. Mol Ecol 12: $1113-$ 1124.

Colquhoun TA, Clark DG. 2011. Unraveling the regulation of floral fragrance biosynthesis. Plant Signal Behav 6: 378-381.

Colquhoun TA, Verdonk JC, Schimmel BC, Tieman DM, Underwood BA, Clark DG. 2010. Petunia floral volatile benzenoid/phenylpropanoid genes are regulated in a similar manner. Phytochemistry 71: $158-167$.

Colquhoun TA, Kim JY, Wedde AE, Levin LA, Schmitt KC, Schuurink RC, Clark DG. 2011. PhMYB4 fine-tunes the floral volatile signature of Petunia $\times$ hybrida through $\mathrm{PhC} 4 \mathrm{H}$. $J$ Exp Bot 62: 1133-1143.

Cooley AM, Willis JH. 2009. Genetic divergence causes parallel evolution of flower color in Chilean Mimulus. New Phytol 183: $729-739$.

Cooley AM, Carvallo G, Willis JH. 2008. Is floral diversification associated with pollinator divergence? Flower shape, flower color and pollinator preference in Chilean Mimulus. Ann Bot 101: 641-650.

Cooley AM, Modliszewski JL, Rommel ML, Willis JH. 2011. Gene duplication in Mimulus underlies parallel floral 
evolution via independent trans-regulatory changes. Curr Biol 21: 700-704.

Danieli-Silva A, de Souza JMT, Donatti AJ, Campos RP, Vicente-Silva J, Freitas L, Varassin IG. 2012. Do pollination syndromes cause modularity and predict interactions in a pollination network in tropical high-altitude grasslands? Oikos 121: 35-43.

Daumer K. 1958. Blumenfarben, wie sie die Bienen sehen. Zeitschrift Physiol 41: 49-110.

Davies KM, Albert NW, Schwinn KE. 2012. From landing lights to mimicry: The molecular regulation of flower coloration and mechanisms for pigmentation patterning. Funct Plant Biol 39: $619-638$.

Des Marais DL, Rausher MD. 2010. Parallel evolution at multiple levels in the origin of hummingbird pollinated flowers in Ipomoea. Evolution 64: 2044-2054.

de Vetten N, Quattrocchio F, Mol J, Koes R. 1997. The an11 locus controlling flower pigmentation in Petunia encodes a novel WD-repeat protein conserved in yeast, plants, and animals. Genes Dev 11: 1422-1434.

Dinkel T, Lunau K. 2001. How drone flies (Eristalis tenax L., Syrphidae, Diptera) use floral guides to locate food sources. $J$ Insect Physiol 47: 1111-1118.

Dudareva N, Negre F, Nagegowda DA, Orlova I. 2006. Plant volatiles: Recent advances and future perspectives. Crit Rev Plant Sci 25: 417-440.

Epperson BK, Clegg MT. 1987. Frequency-dependent variation for outcrossing rate among flower-color morphs of Ipomoea purpurea. Evolution 41: 1302-1311.

Epperson BK, Clegg MT. 1988. Genetics of flower color polymorphism in the common morning glory (Ipomoea purpurea). J Hered 79: 64-68.

Faegri K. 1979. The principles of pollination ecology by K. Faegri and L. van der Pijl. Pergamon Press, Oxford; New York.

Fehr C, Rausher MD. 2004. Effects of variation at the flowercolor A locus on mating system parameters in Ipomoea purpurea. Mol Ecol 13: 1839-1847.

Feinsinger P. 1983. Coevolution and pollination. In Coevolution (ed. Futuyma J, Slatkin M), pp. 283-310. Sinnauer, Sunderland.

Fenster CB, Armbruster WS, Wilson P, Dudash MR, Thomson JD. 2004. Pollination syndromes and floral specialization. Annu Rev Ecol Evol Syst 35: 375-403.

Flagel LE, Wendel JF. 2009. Gene duplication and evolutionary novelty in plants. New Phytol 183: 557-564.

Gerats AGM, Vlaming P, Doodeman M, Al B, Schram AW. 1982. Genetic control of the conversion of dihydroflavonols into flavonols and anthocyanins in flowers of Petunia hybrida. Planta 155: 364-368.

Giurfa M, Núñez J, Chittka L, Menzel R. 1995. Color preferences of flower-naive honeybees. J Comp Physiol A 177: 247-259.

Gonzalez A, Zhao M, Leavitt JM, Lloyd AM. 2008. Regulation of the anthocyanin biosynthetic pathway by the TTG1/ bHLH/MYB transcriptional complex in Arabidopsis seedlings. Plant J 53: 814-827.

Gould KS, Lister C. 2005. Flavonoid functions in plants. In Flavonoids chemistry, biochemistry and applications (ed. Anderson ØM, Markham KR), pp. 397-441. CRC Press, Boca Raton, FL.

Goyret J, Markwell PM, Raguso RA. 2007. The effect of decoupling olfactory and visual stimuli on the foraging behavior of Manduca sexta. J Exp Biol 210: 1398-1405.

Goyret J, Pfaff M, Raguso R, Kelber A. 2008. Why do Manduca sexta feed from white flowers? Innate and learnt color preferences in a hawkmoth. Naturwissenschaften 95: 569-576.

Grotewold E. 2006. The genetics and biochemistry of floral pigments. Annu Rev Plant Biol 57: 761-780.

Gübitz T, Hoballah ME, Dell'Olivo A, Kuhlemeier C. 2009. Petunia as a model system for the genetics and evolution of pollination syndromes. In Petunia: Evolutionary, developmental and physiological genetics (ed. Gerats T, Strommer J), pp. 29-49. Springer, New York.
Gumbert A. 2000. Color choices by bumble bees (Bombus terrestris): Innate preferences and generalization after learning. Behav Ecol Sociobiol 48: 36-43.

Herrera G, Zagal J, Diaz M, Fernández M, Vielma A, Cure M, Martinez J, Bozinovic F, Palacios A. 2008. Spectral sensitivities of photoreceptors and their role in color discrimination in the green-backed firecrown hummingbird (Sephanoides sephaniodes). J Comp Physiol A 194: 785-794.

Hertweck C, Jarvis AP, Xiang L, Moore BS, Oldham NJ. 2001. A mechanism of benzoic acid biosynthesis in plants and bacteria that mirrors fatty acid $\beta$-oxidation. ChemBioChem 2: $784-786$

Hirota SK, Nitta K, Kim Y, Kato A, Kawakubo N, Yasumoto AA, Yahara T. 2012. Relative role of flower color and scent on pollinator attraction: Experimental tests using F1 and F2 hybrids of daylily and nightlily. PLOS ONE 7: e39010.

Hoballah ME, Stuurman J, Turlings TCJ, Guerin PM, Connétable S, Kuhlemeier C. 2005. The composition and timing of flower odor emission by wild Petunia axillaris coincide with the antennal perception and nocturnal activity of the pollinator Manduca sexta. Planta 222: 141-150.

Hoballah ME, Gübitz T, Stuurman J, Broger L, Barone M, Mandel T, Dell'Olivo A, Arnold M, Kuhlemeier C. 2007. Single gene-mediated shift in pollinator attraction in Petunia. Plant Cell 19: 779-790.

Hodges SA, Whittall JB, Fulton M, Yang JY. 2002. Genetics of floral traits influencing reproductive isolation between Aquilegia formosa and Aquilegia pubescens. Am Nat 159: S51-S60.

Holton TA, Cornish EC. 1995. Genetics and biochemistry of anthocyanin biosynthesis. Plant Cell 7: 1071-1083.

Hopkins R, Rausher MD. 2011. Identification of two genes causing reinforcement in the Texas wildflower Phlox drummondii. Nature 469: 411-414.

Hopkins R, Rausher MD. 2012. Pollinator-mediated selection on flower color allele drives reinforcement. Science 335: 1090-1092.

Hopkins R, Levin DA, Rausher MD. 2011. Molecular signatures of selection on reproductive character displacement of flower color in Phlox drummondii. Evolution 66: 469-485.

Johnson ET, Ryu S, Yi H, Shin B, Cheong H, Choi G. 2001. Alteration of a single amino acid changes the substrate specificity of dihydroflavonol 4-reductase. Plant J 25: 325-333.

Johzuka-Hisatomi Y, Hoshino A, Mori T, Habu Y, Iida S. 1999. Characterization of the chalcone synthase genes expressed in flowers of the common and japanese morning glories. Genes Genet Syst 74: 141-147.

Jones CE, Buchmann SL. 1974. Ultraviolet floral patterns as functional orientation cues in hymenopterous pollination systems. Anim Behav 22: 481-485.

Kelber A. 1997. Innate preferences for flower features in the hawkmoth Macroglossum stellatarum. J Exp Biol 200: 827836.

Kelber A, Balkenius A, Warrant EJ. 2002. Scotopic color vision in nocturnal hawkmoths. Nature 419: 922-925.

Kessler D, Gase K, Baldwin IT. 2008. Field experiments with transformed plants reveal the sense of floral scents. Science 321: $1200-1202$.

Kevan P, Giurfa M, Chittka L. 1996. Why are there so many and so few white flowers? Trends Plant Sci 1: 252.

Kingston AB, Mc Quillan PB. 2000. Are pollination syndromes useful predictors of floral visitors in Tasmania? Austral Ecol 25: $600-609$.

Klahre U, Gurba A, Hermann K, Saxenhofer M, Bossolini E, Guerin PM, Kuhlemeier C. 2011. Pollinator choice in Petunia depends on two major genetic loci for floral scent production. Curr Biol 21: 730-739.

Klempien A, Kaminaga Y, Qualley A, Nagegowda DA, Widhalm JR, Orlova I, Shasany AK, Taguchi G, Kish CM, Cooper BR, et al. 2012. Contribution of CoA ligases to benzenoid biosynthesis in Petunia flowers. Plant Cell 24: 2015-2030.

Knapp S. 2010. On "various contrivances": Pollination, phylogeny and flower form in the Solanaceae. Philos Trans $R$ Soc $B$ Biol Sci 365: 449-460. 
Knudsen J, Eriksson R, Gershenzon J, Ståhl B. 2006. Diversity and distribution of floral scent. Bot Rev 72: 1-120.

Koeduka T, Orlova I, Baiga TJ, Noel JP, Dudareva N, Pichersky E. 2009. The lack of floral synthesis and emission of isoeugenol in Petunia axillaris subsp. parodii is due to a mutation in the isoeugenol synthase gene. Plant J 58: 961-969.

Koes R, Verweij W, Quattrocchio F. 2005. Flavonoids: A colorful model for the regulation and evolution of biochemical pathways. Trends Plant Sci 10: 236-242.

Kolosova N, Gorenstein N, Kish CM, Dudareva N. 2001. Regulation of circadian methyl benzoate emission in diurnally and nocturnally emitting plants. Plant Cell 13: 2333-2347.

Kroon AR. 2004. Transcription regulation of the anthocyanin pathway in Petunia hybrida. Vrije Universiteit, Amsterdam.

Kunze J, Gumbert A. 2001. The combined effect of color and odor on flower choice behavior of bumble bees in flower mimicry systems. Behav Ecol 12: 447-456.

Lorenz-Lemke AP, Mäder G, Muschner VC, Stehmann JR, Bonatto SL, Salzano FM, Freitas LB. 2006. Diversity and natural hybridization in a highly endemic species of Petunia (Solanaceae): A molecular and ecological analysis. Mol Ecol 15: $4487-4497$.

Lowry DB, Sheng CC, Lasky JR, Willis JH. 2012. Five anthocyanin polymorphisms are associated with an R2R3-MYB cluster in Mimulus guttatus (Phrymaceae). Am J Bot 99: 82-91.

Lunau K, Papiorek S, Eltz T, Sazima M. 2011. Avoidance of achromatic colors by bees provides a private niche for hummingbirds. J Exp Biol 214: 1607-1612.

Maeda H, Shasany AK, Schnepp J, Orlova I, Taguchi G, Cooper BR, Rhodes D, Pichersky E, Dudareva N. 2010. RNAi suppression of arogenate dehydratase 1 reveals that phenylalanine is synthesized predominantly via the arogenate pathway in Petunia petals. Plant Cell 22: 832-849.

Menzel R, Backhaus W. 1991. Color vision in insects. In Vision and visual dysfunction: The perception of color (ed. Gouras P), pp. 262-293. Macmillan, New York.

Miller RS, Miller RE. 1971. Feeding activity and color preference of ruby-throated hummingbirds. Condor 73: 309-313.

Moerkercke AV, Schauvinhold I, Pichersky E, Haring MA, Schuurink RC. 2009. A plant thiolase involved in benzoic acid biosynthesis and volatile benzenoid production. Plant $J$ 60: $292-302$.

Mol J, Grotewold E, Koes R. 1998. How genes paint flowers and seeds. Trends Plant Sci 3: 212-217.

Morita Y, Saitoh M, Hoshino A, Nitasaka E, Iida S. 2006. Isolation of cDNAs for R2R3-MYB, bHLH and WDR transcriptional regulators and identification of $c$ and $c a$ mutations conferring white flowers in the japanese morning glory. Plant Cell Physiol 47: 457-470.

Negre F, Kish CM, Boatright J, Underwood B, Shibuya K, Wagner C, Clark DG, Dudareva N. 2003. Regulation of methylbenzoate emission after pollination in snapdragon and Petunia flowers. Plant Cell 15: 2992-3006.

Ollerton J, Alarcón R, Waser NM, Price MV, Watts S, Cranmer L, Hingston A, Peter CI, Rotenberry J. 2009. A global test of the pollination syndrome hypothesis. Ann Bot 103: $1471-$ 1480 .

Ômura H, Honda K. 2005. Priority of color over scent during flower visitation by adult Vanessa indica butterflies. Oecologia 142: 588-596.

Orlova I, Marshall-Colón A, Schnepp J, Wood B, Varbanova M, Fridman E, Blakeslee JJ, Peer WA, Murphy AS, Rhodes D, et al. 2006. Reduction of benzenoid synthesis in Petunia flowers reveals multiple pathways to benzoic acid and enhancement in auxin transport. Plant Cell 18: 3458-3475.

Penny JHJ. 1983. Nectar guide color contrast: A possible relationship with pollination strategy. New Phytol 95: 707-721.

Petroni K, Tonelli C. 2011. Recent advances on the regulation of anthocyanin synthesis in reproductive organs. Plant Sci 181: 219-229.

Pichersky E, Gershenzon J. 2002. The formation and function of plant volatiles: Perfumes for pollinator attraction and defense. Curr Opin Plant Biol 5: 237-243.
Qualley AV, Widhalm JR, Adebesin F, Kish CM, Dudareva N. 2012. Completion of the core $\beta$-oxidative pathway of benzoic acid biosynthesis in plants. Proc Natl Acad Sci 109: $16383-$ 16388.

Quattrocchio F. 1994. Regulatory genes controlling flower pigmentation in Petunia hybrida. Vrije Universiteit, Amsterdam.

Quattrocchio F, Wing JF, Leppen HTC, Mol JNM, Koes RE. 1993. Regulatory genes controlling anthocyanin pigmentation are functionally conserved among plant species and have distinct sets of target genes. Plant Cell 5: 1497-1512.

Quattrocchio F, Wing JF, Van der Woude K, Mol JNM, Koes R. 1998. Analysis of bHLH and MYB domain proteins: Speciesspecific regulatory differences are caused by divergent evolution of target anthocyanin genes. Plant $J$ 13: 475-488.

Quattrocchio F, Wing J, van der Woude K, Souer E, de Vetten N, Mol J, Koes R. 1999. Molecular analysis of the anthocyanin2 gene of Petunia and its role in the evolution of flower color. Plant Cell 11: 1433-1444.

Quattrocchio F, Baudry A, Lepiniec L, Grotewold E. 2008. The regulation of flavonoid biosynthesis. In The science of flavonoids (ed. Grotewold E), pp. 97-122. Springer, New York.

Rae JM, Vamosi JC. 2012. Ultraviolet reflectance mediates pollinator visitation in Mimulus guttatus. Plant Species Biology doi:10.1111/j.1442-1984.2012.00375.x.

Raguso RA. 2008. Wake up and smell the roses: The ecology and evolution of floral scent. Annu Rev Ecol Evol Syst 39: $549-569$.

Raguso R, Pichersky E. 1995. Floral volatiles from Clarkia breweri and C. concinna (Onagraceae): Recent evolution of floral scent and moth pollination. Plant Syst Evol 194: 5567.

Raguso RA, Willis MA. 2002a. Hawkmoth pollination in Arizona's Soronan Desert: Behavioral responses to floral traits. In Evolution and ecology taking flight: Butterflies as model systems (ed. Boggs CL, et al.), pp. 43-65. University of Chicago Press, Chicago.

Raguso RA, Willis MA. 2002b. Synergy between visual and olfactory cues in nectar feeding by naive hawkmoths, Manduca sexta. Anim Behav 64: 685-695.

Raguso RA, Willis MA. 2005. Synergy between visual and olfactory cues in nectar feeding by wild hawkmoths, Manduca sexta. Anim Behav 69: 407-418.

Raguso RA, Levin RA, Foose SE, Holmberg MW, McDade LA. 2003. Fragrance chemistry, nocturnal rhythms and pollination "syndromes" in Nicotiana. Phytochemistry 63: 265-284.

Raine NE, Chittka L. 2007. The adaptive significance of sensory bias in a foraging context: Floral color preferences in the bumblebee Bombus terrestris. PLOS ONE 2: e556.

Ramsey J, Bradshaw HD Jr, Schemske DW. 2003. Components of reproductive isolation between the monkeyflowers Mimulus lewisii and M. cardinalis (Phrymaceae). Evolution 57: $1520-1534$.

Rausher MD. 2008. Evolutionary transitions in floral color. Int $J$ Plant Sci 169: 7-21.

Riffell JA, Lei H, Abrell L, Hildebrand JG. 2013. Neural basis of a pollinator's buffet: Olfactory specialization and learning in Manduca sexta. Science 399: 200-204.

Schemske DW, Bradshaw HD. 1999. Pollinator preference and the evolution of floral traits in monkeyflowers (Mimulus). Proc Natl Acad Sci 96: 11910-11915.

Schiestl FP, Dötterl S. 2012. The evolution of floral scent and olfactory preferences in pollinators: Coevolution or pre-existing bias? Evolution 66: 2042-2055.

Schwinn K, Venail J, Shang Y, Mackay S, Alm V, Butelli E, Oyama R, Bailey P, Davies K, Martin C. 2006. A small family of MYB-regulatory genes controls floral pigmentation intensity and patterning in the genus Antirrhinum. Plant Cell 18: $831-851$.

Shang Y, Venail J, Mackay S, Bailey PC, Schwinn KE, Jameson PE, Martin CR, Davies KM. 2011. The molecular basis for venation patterning of pigmentation and its effect on pollinator attraction in flowers of Antirrhinum. New Phytol 189: $602-615$. 
Smith SD, Rausher MD. 2011. Gene loss and parallel evolution contribute to species difference in flower color. Mol Biol Evol 28: $2799-2810$

Smith SD, Ané C, Baum DA. 2008. The role of pollinator shifts in the floral diversification of Iochroma (Solanaceae). Evolution 62: 793-806

Spaethe J, Tautz J, Chittka L. 2001. Visual constraints in foraging bumblebees: Flower size and color affect search time and flight behavior. Proc Natl Acad Sci 98: 3898-3903.

Spelt C, Quattrocchio F, Mol JNM, Koes R. 2000. Anthocyanin1 of Petunia encodes a basic helix-loop-helix protein that directly activates transcription of structural anthocyanin genes. Plant Cell 12: 1619-1631.

Spelt C, Quattrocchio F, Mol J, Koes R. 2002. Anthocyanin1 of Petunia controls pigment synthesis, vacuolar $\mathrm{pH}$, and seed coat development by genetically distinct mechanisms. Plant Cell 14: 2121-2135.

Spitzer-Rimon B, Marhevka E, Barkai O, Marton I, Edelbaum O, Masci T, Prathapani NK, Shklarman E, Ovadis M, Vainstein A. 2010. EOBII, a gene encoding a flower-specific regulator of phenylpropanoid volatiles' biosynthesis in Petunia. Plant Cell 22: 1961-1976.

Stehmann J, Lorenz-Lemke A, Freitas L, Semir J. 2009. The genus Petunia. In Petunia evolutionary, developmental and physiological genetics (ed. Gerats A, Strommer J), pp. 1-28. Springer, New York.

Stracke R, Werber M, Weisshaar B. 2001. The R2R3-MYB gene family in Arabidopsis thaliana. Curr Opin Plant Biol 4: 447-456.

Streisfeld MA, Kohn JR. 2005. Contrasting patterns of floral and molecular variation across a cline in Mimulus aurantiacus. Evolution 59: 2548-2559.

Streisfeld MA, Kohn JR. 2007. Environment and pollinator-mediated selection on parapatric floral races of Mimulus aurantiacus. J Evol Biol 20: 122-132.

Streisfeld MA, Rausher MD. 2009a. Altered trans-regulatory control of gene expression in multiple anthocyanin genes contributes to adaptive flower color evolution in Mimulus aurantiacus. Mol Biol Evol 26: 433-444.

Streisfeld MA, Rausher MD. 2009b. Genetic changes contributing to the parallel evolution of red floral pigmentation among Ipomoea species. New Phytol 183: 751-763.

Stuurman J, Hoballah ME, Broger L, Moore J, Basten C, Kuhlemeier C. 2004. Dissection of floral pollination syndromes in Petunia. Genetics 168: 1585-1599.

Tiffin P, Miller RE, Rausher MD. 1998. Control of expression patterns of anthocyanin structural genes by two loci in the common morning glory. Genes Genet Syst 73: 105-110.

Tornielli G, Koes R, Quattrocchio F. 2009. The genetics of flower color. In Petunia evolutionary, developmental and physiological genetics (ed. Gerats T, Strommer J), pp. 269-299. Springer, New York.

Underwood BA, Tieman DM, Shibuya K, Dexter RJ, Loucas HM, Simkin AJ, Sims CA, Schmelz EA, Klee HJ, Clark DG. 2005. Ethylene-regulated floral volatile synthesis in Petunia corollas. Plant Physiol 138: 255-266.

van der Pijl L. 1960. Ecological aspects of flower evolution: 1. Phyletic evolution. Evolution 14: 403-416.

Van Moerkercke A, Haring MA, Schuurink RC. 2011. The transcription factor EMISSION OF BENZENOIDS II activates the MYB ODORANT1 promoter at a MYB binding site specific for fragrant Petunias. Plant J 67: 917-928.

Van Moerkercke A, Galván-Ampudia CS, Verdonk JC, Haring MA, Schuurink RC. 2012. Regulators of floral fragrance production and their target genes in Petunia are not exclusively active in the epidermal cells of petals. $J$ Exp Bot 63: $3157-$ 3171.

Verdonk JC, Haring MA, Van Tunen AJ, Schuurink RC. 2005. Odorant 1 regulates fragrance biosynthesis in Petunia flowers. Plant Cell 17: 1612-1624.

von Helversen O, Winkler L, Bestmann HJ. 2000. Sulphur-containing "perfumes" attract flower-visiting bats. J Comp Physiol A 186: $143-153$.

Waser NM, Price MV. 1981. Pollinator choice and stabilizing selection for flower color in Delphinium nelsonii. Evolution 35: $376-390$.

Waser NM, Price MV. 1983. Pollinator behavior and natural selection for flower color in Delphinium nelsonii. Nature 302: $422-424$.

Waser NM, Chittka L, Price MV, Williams NM, Ollerton J. 1996. Generalization in pollination systems, and why it matters. Ecology 77: 1043-1060.

Weiss MR. 1997. Innate color preferences and flexible color learning in the pipevine swallowtail. Anim Behav 53: $1043-$ 1052.

Whibley AC, Langlade NB, Andalo C, Hanna AI, Bangham A, Thébaud C, Coen E. 2006. Evolutionary paths underlying flower color variation in Antirrhinum. Science 313: $963-$ 966.

Wijsman HJW. 1983. On the interrelationships of certain species of Petunia II. Experimental data: Crosses between different taxa. Acta Bot Neerlandica 32: 97-107.

Winkel-Shirley B. 2001. Flavonoid biosynthesis. A colorful model for genetics, biochemistry, cell biology, and biotechnology. Plant Physiol 126: 485-493.

Winter Y, Lopez J, von Helversen O. 2003. Ultraviolet vision in a bat. Nature 425: 612-614.

Wright G, Skinner B, Smith B. 2002. Ability of honeybee, Apis mellifera, to detect and discriminate odors of varieties of canola (Brassica rapa and Brassica napus) and snapdragon flowers (Antirrhinum majus). J Chem Ecol 28: 721-740.

Wright G, Lutmerding A, Dudareva N, Smith B. 2005. Intensity and the ratios of compounds in the scent of snapdragon flowers affect scent discrimination by honeybees (Apis mellifera). J Comp Physiol A 191: 105-114.

Zenoni S, D’Agostino N, Tornielli GB, Quattrocchio F, Chiusano ML, Koes R, Zethof J, Guzzo F, Delledonne M, Frusciante L, et al. 2011. Revealing impaired pathways in the an1 1 mutant by high-throughput characterization of Petunia axillaris and Petunia inflata transcriptomes. Plant J 68: 11-27.

Zufall RA, Rausher MD. 2003. The genetic basis of a flower color polymorphism in the common morning glory (Ipomoea purpurea). J Hered 94: 442-448.

Zuker A, Tzfira T, Ben-Meir H, Ovadis M, Shklarman E, Itzhaki H, Forkmann G, Martens S, Neta-Sharir I, Weiss D, et al. 2002. Modification of flower color and fragrance by antisense suppression of the flavanone 3-hydroxylase gene. Mol Breed 9: $33-41$.

Zvi MMB, Spitzer B, Vainstein A. 2006. Navigating the network of floral scent production. Acta Hortic 714: 143-154.

Zvi MMB, Negre-Zakharov F, Masci T, Ovadis M, Shklarman E, Ben-Meir H, Tzfira T, Dudareva N, Vainstein A. 2008. Interlinking showy traits: Co-engineering of scent and color biosynthesis in flowers. Plant Biotechnol J 6: $403-$ 415.

Zvi MMB, Shklarman E, Masci T, Kalev H, Debener T, Shafir S, Ovadis M, Vainstein A. 2012. PAP1 transcription factor enhances production of phenylpropanoid and terpenoid scent compounds in rose flowers. New Phytol 195: 335-345. 


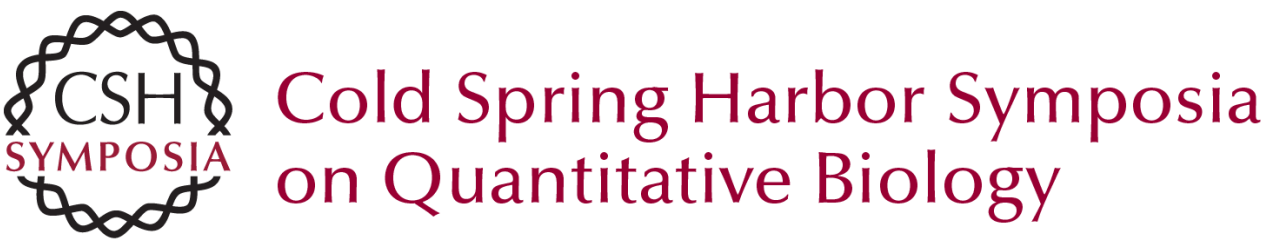

\section{Color and Scent: How Single Genes Influence Pollinator Attraction}

H. Sheehan, K. Hermann and C. Kuhlemeier

Cold Spring Harb Symp Quant Biol 2012 77: 117-133 originally published online March 6, 2013 Access the most recent version at doi:10.1101/sqb.2013.77.014712

References This article cites 135 articles, 31 of which can be accessed free at: http://symposium.cshlp.org/content/77/117.full.html\#ref-list-1

License

Email Alerting Receive free email alerts when new articles cite this article - sign up in Service the box at the top right corner of the article or click here. 